\title{
North Atlantic marine biogenic silica accumulation through the early-to-mid Paleogene: implications for ocean circulation and silicate weathering feedback
}

5 Jakub Witkowski ${ }^{1}$, Karolina Bryłka ${ }^{2}$, Steven M. Bohaty ${ }^{3}$, Elżbieta Mydłowska ${ }^{4}$, Donald E. Penman ${ }^{5}$, Bridget S. Wade ${ }^{6}$

${ }^{1}$ Institute of Marine and Environmental Sciences, University of Szczecin, ul. Mickiewicza 18, 70-383 Szczecin, Poland; ${ }^{2}$ Department of Geology, Faculty of Science, Lund University, Sölvegatan 12, Lund, Sweden

${ }^{3}$ Schoool of Ocean and Earth Science, National Oceanography Centre Southampton, University of Southampton,

10 Waterfront Campus, European Way, Southampton SO14 3ZH, UK

${ }^{4}$ Institute of Spatial Management and Socio-Economic Geography, ul. Mickiewicza 18, 70-383 Szczecin, Poland;

${ }^{5}$ Department of Geosciences, Utah State University, 4505 Old Main Hill, Logan UT 84322, USA

${ }^{6}$ Department of Earth Sciences, University College London, Gower Street, London WC1E 6BT, UK

Correspondence to: Jakub Witkowski (jakub.witkowski@usz.edu.pl)

15 Abstract. The Paleogene history of biogenic opal accumulation in the North Atlantic provides insight into both the evolution of deep-water circulation in the Atlantic basin, and weathering responses to major climate shifts. However, existing records are compromised by low temporal resolution and/or stratigraphic discontinuities. In order to address this problem, we present a multi-site, high-resolution record of biogenic silica $\left(\mathrm{biSiO}_{2}\right)$ accumulation from Blake Nose (ODP Leg 171B, western North Atlantic) spanning the early Paleocene through late Eocene time interval ( 65-34 Ma).

20 This record represents the longest single-locality history of marine ${ }_{b i} \mathrm{SiO}_{2}$ burial compiled to date and offers a unique perspective into changes in bioSiO $\mathrm{S}_{2}$ fluxes through the early-to-mid Paleogene extreme greenhouse interval and

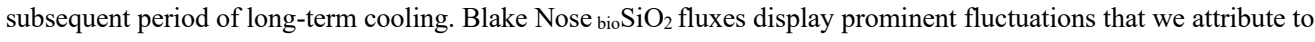
variations in sub-thermocline nutrient supply via cyclonic eddies associated with the Gulf Stream. Whereas few constraints are available on the ${ }_{\text {bio }} \mathrm{SiO}_{2}$ flux pulses peaking in the early Paleocene and early Eocene, a middle Eocene interval of elevated ${ }_{\text {bio }} \mathrm{SiO}_{2}$ flux between $\sim 46$ and $42 \mathrm{Ma}$ is proposed to reflect nutrient enrichment due to invigorated overturning circulation following an early onset of Northern Component Water export from the Norwegian-Greenland

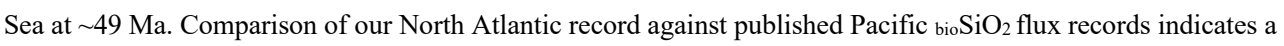
diminished nutrient supply to the Atlantic between 42 and $38 \mathrm{Ma}$, interpreted as a response to weakening of the overturning circulation. Subsequently, a deep-water circulation regime favoring limited bioSiO $\mathrm{Si}_{2}$ burial in Atlantic and enhanced ${ }_{\text {bio }} \mathrm{SiO}_{2}$ burial in the Pacific was established after $\sim 38 \mathrm{Ma}$, likely in association with a further invigoration of deep-water export from the North Atlantic. We also observe that Blake Nose ${ }_{b i o} \mathrm{SiO}_{2}$ fluxes through the middle Eocene cooling interval ( 48 to $34 \mathrm{Ma}$ ) are consistently higher than background fluxes throughout the late Paleocene-early Eocene interval of intense greenhouse warmth. This observation is consistent with a temporally variable rather than constant silicate weathering feedback strength model for the Paleogene, which would instead predict that marine ${ }_{\text {bioSiO}} \mathrm{SiO}_{2}$ burial should peak during periods of extreme warming.

\section{Introduction}

Biogenic silica ( $\mathrm{bioSiO}_{2}$ ) secretion by marine plankton and the subsequent accumulation of biosiliceous marine sediments represent the main output flux in the global silicon cycle (Tréguer and De La Rocha, 2013). The present-day silicon cycle is also closely linked to the carbon cycle, because diatoms - the most successful and efficient bioSiO${ }_{2}$ secreting plankton group in the modern oceans - are also the key marine primary producers (Smetacek, 1999), responsible for up to $40 \%$ of total global net photosynthesis per year. Owing to the ballast effect of their siliceous 
valves, diatoms are extremely efficient at exporting organic carbon $\left(\mathrm{C}_{\mathrm{org}}\right)$ from the surface to the deep ocean and facilitating $\mathrm{C}_{\mathrm{org}}$ burial in marine sediments (Yool and Tyrrell, 2003). This relationship between the silicon and carbon cycles has profound implications for understanding climate change on both long and short timescales in the past, founded on the premise that sedimentary bio $\mathrm{SiO}_{2}$ mass accumulation rates (fluxes) represent the rate of bio $\mathrm{SiO}_{2}$ burial, and, importantly, that the burial rate reflects bio $\mathrm{SiO}_{2}$ production in surface waters at the time of deposition (Ragueneau et al., 2000; Yool and Tyrrell, 2005).

One fundamental control on marine siliceous plankton production is the amount of dissolved silicon supplied to the oceans from terrestrial silicate weathering, a chemical process that ultimately consumes atmospheric $\mathrm{CO}_{2}$ and

50 releases silicic acid and alkalinity to the oceans (i.e., when combined with carbonate burial in the oceans; Walker et al., 1981; Fontorbe et al., 2020; Penman et al., 2020). By moderating atmospheric $\mathrm{CO}_{2}$, the silicate weathering feedback is postulated to operate as a thermostat, maintaining the Earth's surface within a habitable range of temperatures since early in geological history (Kasting, 2019). In today's rapidly warming world, an accurate understanding of the operation of silicate weathering as a climate feedback mechanism is essential.

Past transient greenhouse warming events, such as as the 'hyperthermal' events of the early-to-mid Paleogene (Paleocene and Eocene epochs; 66-34 Ma), offer ancient points of comparison for the present-day warming and future climate scenarios. Existing studies suggest that Paleogene bio $\mathrm{SiO}_{2}$ accumulation patterns are directly linked to variations in continental weathering on both long (Muttoni and Kent, 2007; Cermeño et al., 2015; Renaudie, 2016) and short (Witkowski et al., 2014; Penman, 2016; Penman et al., 2019) timescales. Additionally, large volumes of diatomite and diatom-rich clays deposited on continental shelves during the early Paleogene (e.g., Oreshkina and Aleksandrova, 2007) suggest that the supply of dissolved silicon from continental weathering under the greenhouse climates exerted a strong influence on marine ${ }_{\text {bio }} \mathrm{SiO}_{2}$ accumulation.

In the modern oceans, deep-water circulation also exerts a major control on marine bio $\mathrm{SiO}_{2}$ accumulation patterns throughout the ocean basins. Firstly, ocean circulation determines the distribution and concentration of limiting nutrients $(\mathrm{N}, \mathrm{P}, \mathrm{Fe})$ in deep waters and their upwelling into surface waters where they fuel primary production, and, secondly, circulation impacts bio $\mathrm{SiO}_{2}$ preservation in seafloor sediments (Ragueneau et al., 2000). Most of the presentday biosiliceous production is focused along continental margins, in areas where diatoms can take advantage of nutrients supplied from continental runoff and coastal upwelling (Malviya et al., 2016). A large proportion of bio $\mathrm{SiO}_{2}$, however, is recycled even before settling out of the photic zone (Van Cappellen et al., 2002), since the modern oceans are undersaturated with respect to $\mathrm{SiO}_{2}$ at all depths. Only a fraction of bio $\mathrm{SiO}_{2}$ produced in the photic zone therefore reaches the ocean floor, and, furthermore, only a fraction of the exported $\mathrm{biosiO}_{2}$ is incorporated into sediments and preserved (Frings, 2017).

Both the strength of the silicate weathering feedback and ocean circulation patterns are believed to have undergone profound changes through the early-to-mid Paleogene as the Earth transitioned from a hothouse, ice-free climate state (e.g., Zachos et al., 2008; Kirtland-Turner et al., 2014; Anagnostou et al., 2016) to an icehouse climate marked by continental-scale ice sheets (Zachos et al., 2001; Miller et al., 2020). Isotopic weathering proxies $\left({ }^{87} \mathrm{Sr} /{ }^{86} \mathrm{Sr}\right.$ and $\delta^{7} \mathrm{Li}$ ) display a broad minimum spanning the late Paleocene through early Eocene interval (Misra and Froelich, 2012), which have been interpreted to indicate either flat continental relief through this period (Froelich and Misra, 2015) or evidence for a variable strength of the negative feedback between climate and silicate weathering (Caves et al., 
(Zachos et al., 1996), and the intensification of the Himalayan orogeny are also thought to have altered the dominant weathering regime by facilitating physical rather than chemical weathering, and by exposing large volumes of fresh rock to erosion and weathering (Cermeño et al., 2015).

The early Cenozoic was a time of low thermal gradients between surface and deep waters and between high and low latitudes, which limited vigorous overturning circulation (Vahlenkamp et al., 2018). There is, however, little consensus on the timing of the onset of Northern Component Water (NCW) production, a precursor to today's North Atlantic Deep Water. Estimates vary from the late early Eocene ( 49-50 Ma; Hohbein et al., 2012) through the late Eocene ( $\sim 38 \mathrm{Ma}$; e.g., Borrelli et al., 2014; Coxall et al., 2018) to across the EOT interval ( $\sim 34 \mathrm{Ma}$; Via and Thomas, 2006; Abelson and Erez, 2017). Regardless, the long-term global cooling spanning the middle and late Eocene ( 48-34 $\mathrm{Ma}$ ) is thought to have resulted in enhanced upwelling, and the opening of the Drake Passage is viewed as a milestone in establishing the global pattern of thermohaline circulation in its present-day form in the Atlantic (Via and Thomas, 2006; Abelson and Erez, 2017).

Despite the importance of siliceous biota in the present-day carbon cycle, our understanding of the temporal trends in marine bio $\mathrm{SiO}_{2}$ accumulation through the early Paleogene is limited. First-order observations indicate an association between peak chert/porcellanite occurrence and deep-water temperatures through the Early Eocene Climatic Optimum (EECO) (Muttoni and Kent, 2007) and during short-lived hyperthermal events of the early Eocene (Penman et al., 2019). The rapid cooling at the end of the Eocene is also widely regarded as the period of diatom proliferation and diversification, especially in the Southern Ocean (Egan et al., 2013; Lazarus et al., 2014; Renaudie, 2016). However, trends in marine ${ }_{\text {bio }} \mathrm{SiO}_{2}$ accumulation in the period between these temporally broadly isolated events representing contrasting climate states, are not well understood. The longest currently available perspective on marine bioSiO accumulation (Cretaceous through Miocene) is based on Deep-Sea Drilling Project (DSDP) Leg 1 through 44 smearslide data (i.e., data gathered between 1968 and 1978) converted to mass accumulation rates and binned into 10-millionyear (Myr) increments (Miskell et al., 1985). Direct sediment measurements of bio $\mathrm{SiO}_{2}$ concentrations (with calculated fluxes) through the Paleogene are sparse (e.g., Diester-Haass, 1995; Salamy and Zachos, 1999; Diekmann et al., 2004;

105 Lyle et al., 2005; Iwasaki et al., 2014), and mostly focus on restricted time windows of the late Eocene through early Oligocene interval. A major reason for this is that $\mathrm{bios}_{2}$ is highly vulnerable to water-column and seafloor dissolution, which results in early Paleogene siliceous phytoplankton occurrences often being confined to narrow stratigraphic intervals at many sites (see Barron et al., 2015; Witkowski et al., 2020b).

The observations summarized above provoke three fundamental questions: (1) $\mathrm{How}$ did ${ }_{b i} \mathrm{SiO}_{2}$ burial flux

110 evolve through the early-to-mid Paleogene?; (2) What were the main controls on changes in marine bioSiO$_{2}$ burial in this time interval?; and (3) What was the ${ }_{b i o} \mathrm{SiO}_{2}$ burial response to long-term Paleogene climate changes? Through the early Paleogene, bioSiO 2 accumulation was largely focused in the Atlantic and on the Eurasian Platform (Miskell et al., 1985; Muttoni and Kent, 2007; Moore et al., 2008; Barron et al., 2015; Wade et al., 2020). Unusually expanded lower Paleocene through upper Eocene biosiliceous successions were recovered from Blake Nose in the mid-latitude western

115 North Atlantic (Shipboard Scientific Party, 1998a-f; Witkowski et al., 2020a). In order to gain a quantitative insight into how bio $\mathrm{SiO}_{2}$ burial evolved through the early Paleogene hothouse and the ensuing period of global cooling, we have generated a composite high-resolution Blake Nose ${ }_{\text {bio }} \mathrm{SiO}_{2}$ flux record from $\sim 65$ to $34 \mathrm{Ma}$, spanning nearly the entire Paleocene and Eocene epochs. This work follows on from two previous publications with a focus on the Blake Nose early-to-mid Paleogene siliceous microfossils: (1) Witkowski et al. (2020a), in which a revised chronological 
120 framework is proposed for Site 1050 and 1051, and (2) Witkowski et al. (2020b), in which Paleogene trends in chert and porcellanite occurrences were compared to spatial and temporal patterns in Atlantic biosiliceous sediment occurrences. Here, we aim to determine the main controls on $\mathrm{biSiO}_{2}$ fluxes in a key locus of biosiliceous accumulation in the Northwest Atlantic (Blake Nose) during the early-to-mid Paleogene - a period of Cenozoic climate change characterized by profound variations in global temperature.

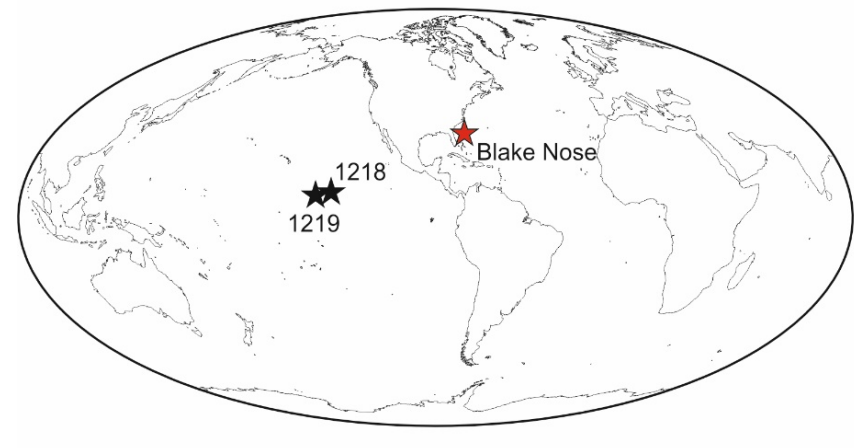

(A)

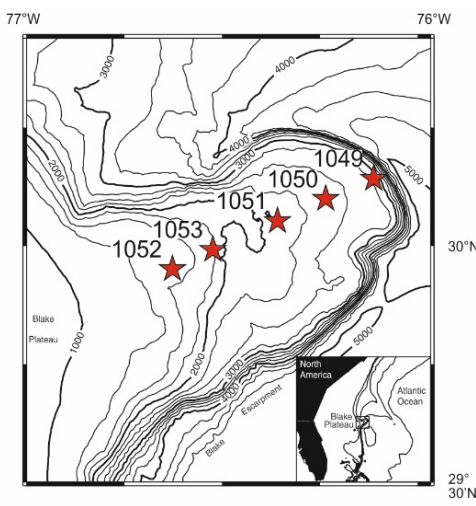

(B)

Figure 1. Maps showing the location of sites considered in the present paper. (A) Blake Nose (red star) in the western North Atlantic and Eastern Equatorial Pacific sites (black stars). Base map generated using Ocean Drilling Stratigraphic Network Advanced Plate Tectonic Reconstruction service (www.odsn.de). (B) Location of the Ocean Drilling Program (ODP) Leg 171B sites on Blake Nose. Modified from Shipboard Scientific Party (1998a).

\begin{tabular}{|c|c|c|c|c|c|}
\hline $\begin{array}{l}\text { ODP } \\
\text { Hole }\end{array}$ & Latitude & Longitude & $\begin{array}{l}\text { Water } \\
\text { depth } \\
\text { (m) }\end{array}$ & Reference & $\begin{array}{l}\text { Number of samples } \\
\text { examined for bioSiO }\end{array}$ \\
\hline 1049A & $30^{\circ} 08.5436^{\prime} \mathrm{N}$ & $76^{\circ} 06.7312^{\prime} \mathrm{W}$ & 2656.1 & Shipboard Scientific Party (1998b) & 70 \\
\hline$\underline{1050 A}$ & $30^{\circ} 05.9977^{\prime} \mathrm{N}$ & $76^{\circ} 14.1011^{\prime} \mathrm{W}$ & 2299.8 & Shipboard Scientific Party (1998c) & 273 \\
\hline $1050 \mathrm{C}$ & $30^{\circ} 05.9953^{\prime} \mathrm{N}$ & $76^{\circ} 14.0997^{\prime} \mathrm{W}$ & 2296.5 & Shipboard Scientific Party (1998c) & 7 \\
\hline$\underline{1051 A}$ & $30^{\circ} 03.1740^{\prime} \mathrm{N}$ & $76^{\circ} 21.4580^{\prime} \mathrm{W}$ & 1982.7 & Shipboard Scientific Party (1998d) & 762 \\
\hline 1052B & $29^{\circ} 57.0791 ’ \mathrm{~N}$ & $76^{\circ} 37.6098^{\prime} \mathrm{W}$ & 1345.0 & Shipboard Scientific Party (1998e) & 13 \\
\hline $1052 F$ & $29^{\circ} 57.0794 ’ \mathrm{~N}$ & $76^{\circ} 37.6094 ’ \mathrm{~W}$ & 1343.5 & Shipboard Scientific Party (1998e) & 26 \\
\hline$\underline{1053 A}$ & $29^{\circ} 59.5385^{\prime} \mathrm{N}$ & $76^{\circ} 31.4135^{\prime} \mathrm{W}$ & 1629.5 & Shipboard Scientific Party (1998f) & 79 \\
\hline
\end{tabular}




\begin{tabular}{|l|l|l|l|l|}
\hline & & & Total samples examined & 1230 \\
\hline
\end{tabular}

Table 1. Sites included in this study, along with geographic coordinates, site chapters, and number of samples examined for bioSiO 2 . Sites used for bio $\mathrm{SiO}_{2}$ flux calculations are underlined.

\section{Materials and methods}

\subsection{Study sites and stratigraphy}

This study is focused on drillcores recovered as part of the Ocean Drilling Program (ODP) Blake Nose

135 Paleoceanographic Transect and includes Holes 1049A, 1050A/C, 1051A, 1052B/F and 1053A (Shipboard Scientific Party, 1998b-f) (Fig. 1) (Table 1). The transect was drilled on Blake Nose (BN; also often referred to as 'Blake Ridge') in the western North Atlantic Ocean in order to reconstruct the Cretaceous-Paleogene paleoceanographic history of the region adjacent to the South Atlantic Bight (Shipboard Scientific Party, 1998a), offshore of the southeastern U.S. seaboard between Florida Straits and Cape Hatteras (Gula et al., 2016). The BN is a northeast-trending extension of the

140 Blake Plateau comprised of a Cretaceous to Paleogene continental margin succession (Pinet et al., 1981; Shipboard Scientific Party, 1998a) (Fig. 1B). As Paleogene sediments draping BN were deposited on the seaward slope of a large reef formed in the Early Cretaceous, the transect sites likely retain the relative depths of the paleo reef system (Shipboard Scientific Party, 1998a). Drilling at BN, as well as at sites further north along the North American margin, documented well-preserved early Paleogene siliceous microfossils (e.g., Gombos, 1982; Nishimura, 1992; Hollis,

145 2014). The BN transect sites that recovered the most expanded early-to-mid Paleogene sections (Sites 1050 and 1051 ) include only a few narrow chert and porcellanite-bearing intervals (Witkowski et al., 2020b), and sparse clinoptilolite occurrences, which suggests minimal diagenesis of sedimentary bio $\mathrm{SiO}_{2}$. As such, the good overall preservation of siliceous microplankton in Paleogene sediments at BN, combined with the exceptionally long stratigraphic span of the record recovered during Leg 171B (Witkowski et al., 2020a, and references therein), makes the BN transect especially

150 well-suited for reconstructing variations in bio $\mathrm{SiO}_{2}$ burial flux in the early Paleocene through late Eocene time period. To this end, we examined 1230 samples from five BN drillsites: Sites 1049, 1050, 1051, 1052, and 1053.

Site 1049 is the most distal and deepest site included in this study (1000-2000 m paleodepth; Shipboard Scientific Party, 1998b) (Fig. 1B; Table 1). The Paleogene section of Hole 1049A was poorly recovered due to the extensive presence of chert horizons. As a consequence, numerous biostratigraphic datums are poorly constrained

155 through the recovered sequence, and age control is only approximate, especially through the Early-Middle Eocene Transition (EMET). Based on the recent revisions to the bio-magnetostratigraphy of Holes 1050A and 1051A, however, Witkowski et al. (2020b) proposed a revised age model for the Paleocene through Eocene interval of Hole 1049A. Here, we examine 70 samples from the chert-free, siliceous microfossil-bearing interval of Hole 1049A, spanning Cores 1049A-3H through -12X ( 21.1 to 88.1 compacted meters below seafloor [cmbsf - see Witkowski et al., 2020a]; Table

160 1). Due to incomplete recovery and the temporal patchiness of the record, however, we do not include data from Hole 1049A in bio $\mathrm{SiO}_{2}$ flux calculations.

Site 1050 (1000-2000 m paleodepth; Shipboard Scientific Party, 1998c) was drilled several km upslope of Site 1049 (Fig. 1B; Table 1). The Paleogene succession cored in Holes 1050A and 1050C is considerably more expanded and stratigraphically more complete than in Hole 1049A. Siliceous microfossils occur throughout the succession cored 165 in Hole 1050A, but in Hole 1050C siliceous microfossils are confined to Core 1050C-2R (Witkowski et al., 2020b). We 
apply the age model of Witkowski et al. (2020a), who interpreted the presence of two major stratigraphic gaps. For this study, we examined 273 samples from Hole 1050A (Cores 1050A-2H through -36X; 11 to $319.3 \mathrm{cmbsf}$ ) and 7 samples from Hole 1050C (Core 1050C-2R; 328 to $336 \mathrm{cmbsf}$ ).

Site 1051, the intermediate-depth site of the BN Transect (1000-2000 m paleodepth; Shipboard Scientific 170 Party, 1998d) (Fig. 1B; Table 1), recovered the most expanded lower Paleocene through upper Eocene succession among Leg 171B sites. Siliceous microfossils occur throughout this succession, except for within several narrow dissolution intervals (for details see Witkowski et al., 2020b). We use the age model of Witkowski et al. (2020a), who showed that the Hole 1051A succession is interrupted by two major gaps that are broadly correlative to the hiatuses in Hole 1050A (see also Röhl et al., 2003). A total of 762 samples from the entire succession cored at Hole 1051A ( $~ 8.5$ to

$175644 \mathrm{cmbsf}$ ) were examined for this study.

Site 1052 is the shallowest site of the BN transect sites, drilled near the crest of the BN (Fig. 1B; Table 1). Most of the middle bathyal (600-1000 m paleodepth; Shipboard Scientific Party, 1998e) Paleogene succession at this site is truncated by a prominent hiatus. In this study, we include a narrow composite interval of Holes 1052B and 1052F ( 77 to 131 meters composite depth [mcd]) spanning the Middle-Late Eocene Turnover (MLET) (Kamikuri and Wade,

180 2012). As this interval overlaps with parts of Holes $1051 \mathrm{~A}$ and $1053 \mathrm{~A}$, it is not considered in sediment flux calculations. For age control at Site 1052, we use the bio-magnetostratigraphic constraints from Shipboard Scientific Party (1998e), Ogg and Bardot (2001), and Wade et al. (2012), following Witkowski et al. (2020b). A total of 39 samples from Site 1052 were used in this study.

Site 1053 was drilled between Sites 1051 (intermediate depth) and 1052 (shallowest depth), in the upper part of the BN transect (500-700 m paleodepth; Shipboard Scientific Party, 1998f) (Fig. 1B; Table 1). Site 1053 recovered an expanded siliceous microfossil-rich upper Eocene section with no detectable stratigraphic gaps, as indicated by the age model of Borrelli et al. (2014). At total of 79 samples from Hole 1053A ( $\sim 0.5$ to 183 meters below sea floor [msbf]) were examined for this study.

Despite two major discontinuities and multiple recovery gaps, our composite $\mathrm{BN}$ record is comprised of data from five sites, and spans the earliest Paleocene ( 64.74 Ma; Magnetochron C28n in Hole 1051A, Witkowski et al., 2020a) through latest Eocene ( 33.94 Ma; Magnetochron C13r in Hole 1053A; Borrelli et al., 2014) interval. This composite represents the longest currently available single-locality record of deep-sea biosiliceous sedimentation through the Paleogene. We report all ages relative to the Gradstein et al. (2012) timescale, hereafter referred to as GTS2012.

\section{2 bio $\mathrm{SiO}_{2}$ measurements}

${ }_{\text {bio }} \mathrm{SiO}_{2}$ concentrations were determined by means of a Hach DR-3900 spectrophotometer, using Hach method 8186 (heteropoly blue method). All spectrophotometric analyses closely followed the wet alkaline extraction procedure of Olivarez Lyle and Lyle (2002). Unlike Olivarez Lyle and Lyle (2002), however, for base extraction we used 1M $\mathrm{KOH}$ and $10 \mathrm{mg}$ ground sediment subsamples rather than $2 \mathrm{M} \mathrm{KOH}$ and $20 \mathrm{mg}$ subsamples. This was done in order to

200 avoid $\mathrm{SiO}_{2}$ polymerization (Annette Olivarez Lyle, written communication, 2015), manifested by the precipitation of whitish filaments in test tubes following base extraction conducted at higher $\mathrm{KOH}$ concentrations with larger 
subsamples. bioSiO 2 concentrations for individual sites are tabulated in Supplementary Tables S1 through S5, and data used for $\mathrm{bioSiO}_{2}$ flux calculations are presented in Supplementary Figures S1-S3 in the online Supplementary Materials.

Three methods were employed to monitor analytical precision of the ${ }_{\text {bio }} \mathrm{SiO}_{2}$ measurements: (1) One sample in each analyzed batch was subject to stepwise standard addition against a target curve, using liquid $\mathrm{SiO}_{2}$ standard supplied by Hach (average target curve $\mathrm{R}^{2}=0.994, \mathrm{n}=84$ ); (2) One random sample from every sample batch was also analyzed in duplicate, with good correlation between duplicate analyses (average $\mathrm{R}^{2}=0.98, \mathrm{n}=92$; online Supplementary Materials Fig. S4); and (3) one of three in-house consistency standards was analyzed in approximately every second sample batch.

\subsection{Sediment mass accumulation rate calculations}

All sediment mass accumulation rate (hereafter: flux) values in this work are expressed as $\mathrm{g} / \mathrm{cm}^{2} /$ thousand years (kyrs), and are calculated using standard terms from previous studies (e.g., Diester-Haass, 1995; Piela et al., 2012; D’haenens et al., 2014):

$\operatorname{MAR}\left(\mathrm{g} / \mathrm{cm}^{2} / \mathrm{kyrs}\right)=$ sedimentary component $[\mathrm{g}$ component $/ \mathrm{g}$ bulk sediment $] \times$ linear sedimentation rate (LSR) $[\mathrm{cm} / \mathrm{kyr}] \times$ sediment dry bulk density $(\mathrm{DBD})\left[\mathrm{g} / \mathrm{cm}^{3}\right]$

Use of magneto-biostratigraphic age models to establish LSRs typically produces unrealistic jumps in sediment flux estimates at magnetostratigraphic boundaries, with order-of-magnitude differences between consecutive age-model tiepoints. In order to smooth out such abrupt features, which we deem to be artifacts of the applied age models, in our flux records, we fitted polynomial regressions against the age vs depth curves (or segments thereof comprised between hiatuses), following the approach of Piela et al. (2012). The datasets developed in the present work are based on several holes that include several hiatuses, and robust age models that are consistent between holes are essential to obtain a reliable composite stratigraphy. We therefore plot the flux records derived from smoothed LSR estimates using ages interpolated from the original (i.e., non-smoothed) age-depth curves (Figs S1-S3).

Sediment flux studies often estimate wet bulk sediment density through calibration of high-resolution estimates of wet bulk density (obtained via gamma ray attenuation [GRA] analysis) against discrete DBD measurements collected during routine shipboard analysis. In the present work, establishing a single GRA-DBD correlation over the entire cored interval proved ineffective for Sites 1050 and 1051, likely due to the downhole increase in compaction. Instead, we estimated DBD for a given depth by interpolating between shipboard discrete DBD measurements (Shipboard Scientific Party, 1998b-d, f). Sediment density plots, LSRs, and calculated fluxes are included in the online Supplementary Materials (Figs S1-S3 and Tables S2-S3, S5).

\subsection{Stable isotope and $p \mathrm{CO}_{2}$ data}

Our interpretation of possible controls on early-to-mid Paleogene bioSiO$_{2}$ accumulation is based on comparison to published isotopic weathering $\left({ }^{87} \mathrm{Sr} /{ }^{86} \mathrm{Sr},{ }^{187} \mathrm{Os} /{ }^{188} \mathrm{Os}\right.$ and $\delta^{7} \mathrm{Li}$; Ravizza et al., 2001; Ravizza and Peucker-Ehrenbrink, 2003; Misra and Froelich, 2012; Klemm et al., 2005) and paleocirculation proxies ( $\delta^{13} \mathrm{C}, \delta^{18} \mathrm{O}$; Cramer et al., 2009), as

235 well as the recent atmospheric $p \mathrm{CO}_{2}$ reconstruction (Foster et al., 2017), and silicate weathering flux model (hereafter SWF) (Caves et al., 2016). For further discussion and a full documentation of data sources see the online Supplementary Materials (Supplementary Text and Figure S5). 


\subsection{Statistical treatment}

Smoothed long-term trends in $\mathrm{biSiO}_{2}$ flux and published geochemical records were obtained via LOESS regression (Cleveland et al., 1992), computed using R Studio v. 3.5.1. Statistical analysis was performed on smoothed time series (bioSiO 2 flux, $\delta^{13} \mathrm{C}, \delta^{18} \mathrm{O}, p \mathrm{CO}_{2}{ }^{87} \mathrm{Sr} /{ }^{86} \mathrm{Sr},{ }^{187} \mathrm{Os} /{ }^{188} \mathrm{Os}, \delta^{7} \mathrm{Li}$ and $\mathrm{SWF}$ ) using Statistica 13.1 package.

The degree of covariance of the analyzed variables was assessed by correlation analysis. Normality test procedure was carried out for all variables using the Shapiro-Wilk test $(\alpha=0.05)$. The Pearson correlation coefficient was used to assess covariance for each pair of variables characterized by a normal distribution. The non-parametric Spearman correlation coefficient was used when non-normal distribution was indicated for a given variable by the Shapiro-Wilk test.

The analysis also involved a multiple regression model, which describes the relationship of the dependent variable $\mathrm{Y}$ with a set of independent variables $\mathrm{X}_{1}, \mathrm{X}_{2}, \ldots, \mathrm{X}_{\mathrm{k}}$ (which, in this study, is the relationship between bio $\mathrm{SiO}_{2}$ flux and other proxy records). It is defined by Eq. (1):

$Y=\beta_{0}+\beta_{1} X_{1}+\beta_{2} X_{2}+\cdots+\beta_{k} X_{k}+\xi$

Where:

$\beta_{\mathrm{j}}-$ model parameters (regression coefficient)

$\xi$ - random component

255 The parameters of the regression equation are estimated using least squares method, and determination coefficient and standard error of estimation are used to assess the goodness of the model. 

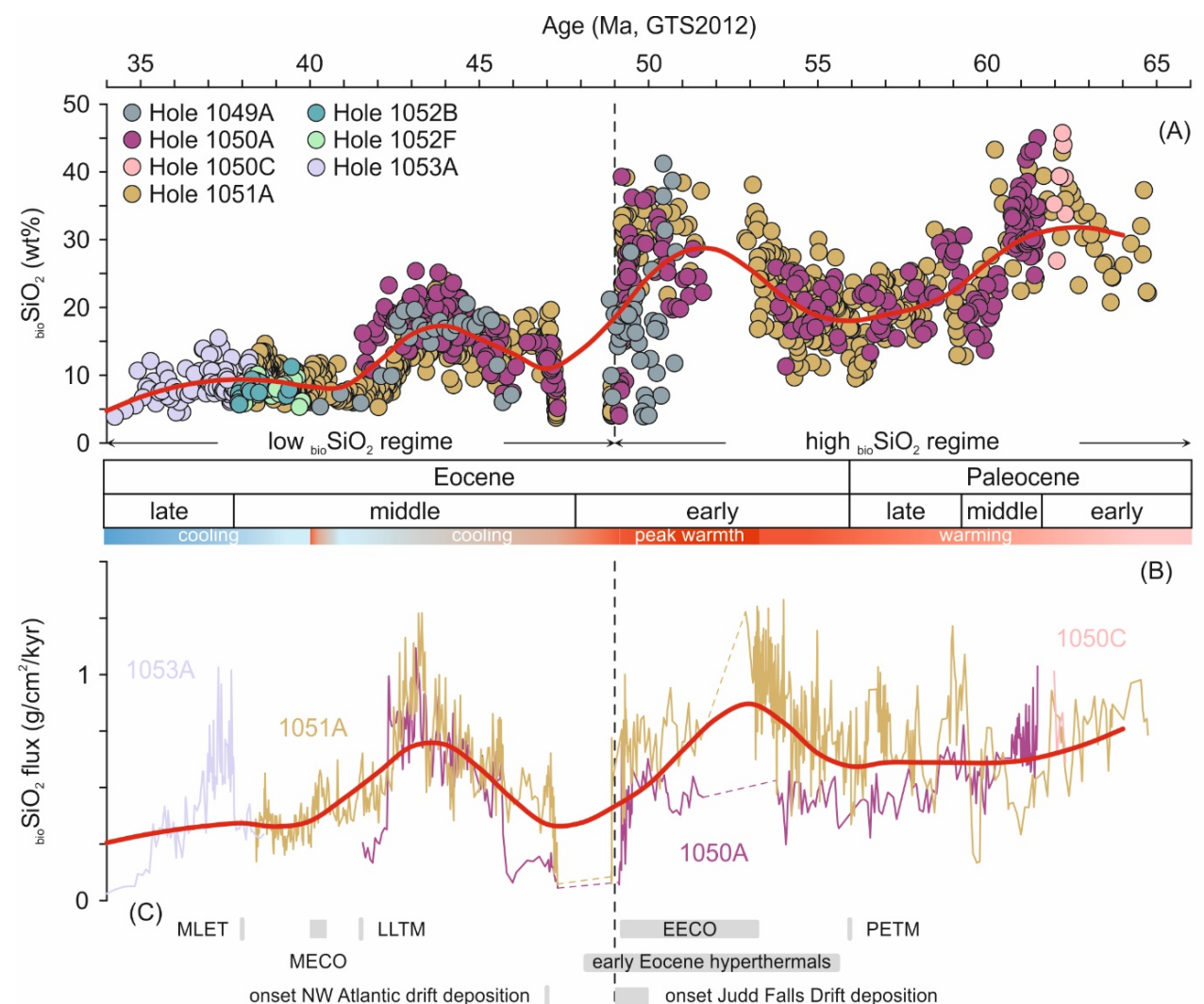

(B)

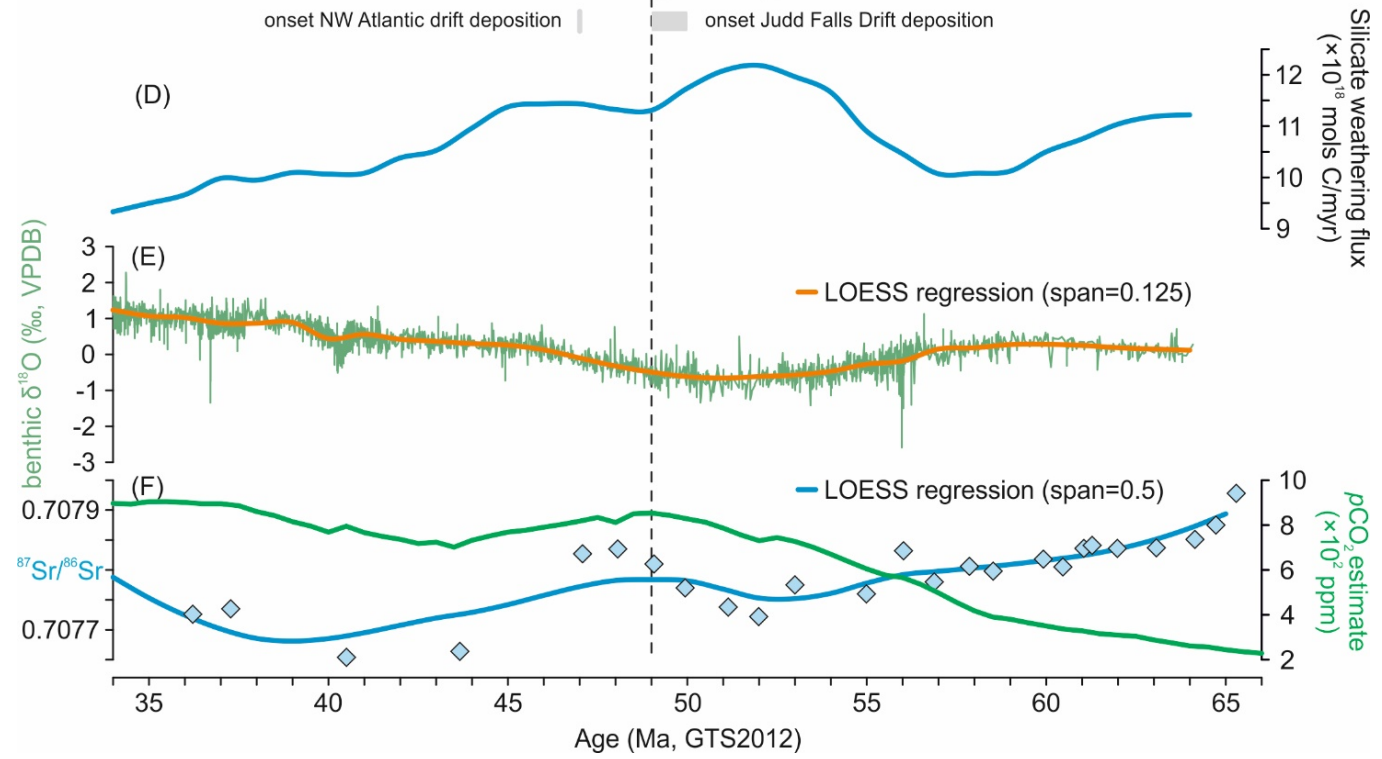

Figure 2. Composite Blake Nose weight per cent biogenic silica concentrations (A) and fluxes (B) through the early-tomid Paleogene plotted against key tectonic and climatic events (C), silicate weathering flux as modelled by Caves et al. (2016) (D), global benthic foraminiferal $\delta^{18} \mathrm{O}$ compilation of Cramer et al. (2009; rescaled to GTS2012) (E), and $p \mathrm{CO}_{2}$ reconstruction (Foster et al., 2017) and ${ }^{87} \mathrm{Sr} /{ }^{86} \mathrm{Sr}$ ratios (Misra and Froelich, 2012) (F). Schematic representation of 
climatic trends next to chronostratigraphy panel is consistent with Cramwinckel et al. (2018). Abbreviations: wt\% - weight per cent; bioSiO 2 - biogenic silica; GTS2012 - Geologic Time Scale 2012, see Gradstein et al. (2012).

\section{Results and interpretation}

Our new composite \% $\mathrm{bisiO}_{2}$ record from Blake Nose spans the interval between $\sim 65$ and $34 \mathrm{Ma}$ (Fig. 2A), representing the longest single-locality record of ${ }_{b i o} \mathrm{SiO}_{2}$ concentrations compiled to date. The composite record, however, lacks data in two short time windows: between $~ 53.5$ and 52.0 Ma (Magnetochrons C24n through C23n) and between $\sim 47.5$ and $49.0 \mathrm{Ma}$ (i.e., through the EMET). This is due to the presence of prominent hiatuses at all study sites spanning these intervals (Shipboard Scientific Party, 1998b-d; Witkowski et al., 2020a) (Fig. 2A).

The $\mathrm{BN} \% \mathrm{bioSiO}_{2}$ composite shows variable but generally high values between $\sim 65$ and $49 \mathrm{Ma}$ (Fig. $2 \mathrm{~A}$ ). Two broad $\%$ bio $\mathrm{SiO}_{2}$ maxima are observed within this high-bio $\mathrm{SiO}_{2}$ interval, culminating at $\sim 61.5 \mathrm{Ma}$ and at $\sim 51.5 \mathrm{Ma}$ (Fig. $2 \mathrm{~A})$. These maxima are separated by a broad low in $\% \mathrm{obio}_{2}$ with a nadir centered at approximately the PaleoceneEocene boundary ( $\sim 56 \mathrm{Ma}$ ). From $\sim 49 \mathrm{Ma}$ to the end of the record at $\sim 34 \mathrm{Ma}, \%$ bio $\mathrm{SiO}_{2}$ levels are considerably lower and less variable (Fig. 2A), with a distinct maximum culminating at $\sim 44 \mathrm{Ma}$.

Long-term trends in $\mathrm{BN}_{\text {bio }} \mathrm{SiO}_{2}$ fluxes are calculated based on a composite record built from datasets generated from Sites 1050, 1051, and 1053. Through the Paleocene and early Eocene, Site 1050 generally displays lower bioSiO fluxes than Site 1051 (Fig. 2B). From $\sim 6$ to $34 \mathrm{Ma}$, both bio $\mathrm{SiO}_{2}$ flux trends and values are remarkably consistent between Sites 1050 and 1051 (Fig. 2B). The short time interval in which records from Site 1051 and Site 1053 overlap also reveals coherent ${ }_{\text {bio }} \mathrm{SiO}_{2}$ flux values (Fig. 2B). Thus, following a period of high inter-site variability through the

Paleocene, three intervals of elevated ${ }_{b i o} \mathrm{SiO}_{2}$ fluxes are observed, which are consistent between sites and peak at $\sim 53.2$ $\mathrm{Ma}, \sim 43.3 \mathrm{Ma}$, and at $\sim 37.7 \mathrm{Ma}$. The overall patterns in \%bio $\mathrm{SiO}_{2}$ and $\mathrm{biosi}_{2}$ flux estimates are also consistent, especially through the middle and late Eocene. Most importantly, however, the ${ }_{b i S i O} \mathrm{Silux}_{2}$ values fall within the same order of magnitude through most of the study period (except for peak bioSiO $\mathrm{S}_{2}$ fluxes at Site 1051 between 54 and $53 \mathrm{Ma}$ and from 44 to $43 \mathrm{Ma}$ ). Furthermore, our record consistently shows that $\mathrm{biSiO}_{2}$ fluxes through the middle Eocene 285 cooling were, on average, higher than (Site 1050) or similar to (Site 1051) bioSiO $\mathrm{Si}_{2}$ fluxes through the early Eocene period of extreme greenhouse warmth (Fig. 2B).

\subsection{Impact of hiatuses and diagenesis on $\mathrm{BN}_{\text {bio }} \mathrm{SiO}_{2}$ flux estimates}

The records from Sites 1050 and 1051, which constitute the older part of the composite presented here, are interrupted by hiatuses. These discontinuities in the $\mathrm{BN}$ record could introduce a bias to the flux estimates, for instance by influencing the LSR calculations. The age models for Holes 1050A/C and 1051A used in this study (see Witkowski et al., 2020a, for details), however, are highly consistent in that the hiatuses are identified in correlative intervals, and furthermore - LSRs used in flux calculations were subjected to polynomial smoothing, which should eliminate most short-term artifacts imposed by age model imperfections. bioSiO 2 flux estimates could also be compromised by winnowing, which could concentrate biosiliceous particles over some areas of the seabed, while removing them from adjacent areas. In the core description logs for $\mathrm{BN}$ sites included in the present bio $\mathrm{SiO}_{2}$ flux reconstruction, explicit mention of winnowing is made only in one instance, i.e., for Core 1051A-41X (Shipboard Scientific Party, 1998d). This core also includes abundant zeolite crystals (J. Witkowski, unpub. observations), which are an indicator of bio $\mathrm{SiO}_{2}$ diagenesis (see Fenner, 1991). For this reason, Core 1051A-41X was excluded from the present study. Also, no 
$\% \mathrm{obiO}_{2}$ measurements were performed on the sparse cherty or porcellanitic intervals at Sites 1050 and 1051 . Scanning electron micrograph examination of diatoms from the remaining intervals of the BN composite indicates only minor diagenetic effects on the siliceous microfossils, manifested mostly by the dissolution of the most delicate parts of the valves, such as areole occlusions or pore fields. For these reasons, the $\mathrm{bio}_{\mathrm{O}} \mathrm{SiO}_{2}$ fluxes reconstructed in this study are deemed to be robust.

3.2 Controls on bioSiO ${ }_{2}$ accumulation through the early-to-mid Paleogene at Blake Nose

bio $\mathrm{SiO}_{2}$ production, export, and preservation in marine sediments are influenced globally by dissolved silicon supply to the oceans derived from terrestrial weathering, which is closely linked to climate via a negative feedback (e.g., Walker et al., 1981), and by ocean circulation patterns and upwelling, which supply the bulk of nutrients to surface waters (Miskell et al., 1985; Handoh et al., 2003). In order to gain insight into the influence that each of these factors has exerted on bio $\mathrm{SiO}_{2}$ accumulation through the early-to-mid Paleogene at Blake Nose, we compared the bio $\mathrm{SiO}_{2}$ flux composite record to published composite global benthic foraminiferal $\delta^{18} \mathrm{O}$ and $\delta^{13} \mathrm{C}$ records, $p \mathrm{CO}_{2}$ proxy estimates, proxy records of continental weathering $\left({ }^{87} \mathrm{Sr} /{ }^{86} \mathrm{Sr},{ }^{187} \mathrm{Os} /{ }^{188} \mathrm{Os}\right.$ and $\left.\delta^{7} \mathrm{Li}\right)$, and modelled silicate weathering flux (SWF) (Fig. 2, Fig. S5).

We find that ${ }_{b i o} \mathrm{SiO}_{2}$ flux is moderately correlated to modelled $\mathrm{SWF}(\mathrm{r}=0.597, \mathrm{p}<0.05)$, and more strongly, but inversely correlated to both $p \mathrm{CO}_{2}(\mathrm{r}=-0.775, \mathrm{p}<0.05)$, and $\delta^{18} \mathrm{O}(\mathrm{r}=-0.618, \mathrm{p}<0.05)$ (Fig. 3). A weaker, but still

315 statistically significant, correlation exists between bioSiO$_{2}$ flux and $\delta^{7} \mathrm{Li}(\mathrm{r}=-0.473, \mathrm{p}<0.05),{ }^{187} \mathrm{Os} /{ }^{188} \mathrm{Os}(\mathrm{r}=0.430$, $\mathrm{p}<0.05$ ), and ${ }^{87} \mathrm{Sr} /{ }^{86} \mathrm{Sr}(0.418, \mathrm{p}<0.05)$ (Fig. 3). No statistically significant correlation has been found between bio $\mathrm{SiO}_{2}$ flux and trends in benthic foraminiferal $\delta^{13} \mathrm{C}$. These relationships suggest that overall, through the early-to-mid Paleogene, bio $\mathrm{SiO}_{2}$ flux at $\mathrm{BN}$ was indirectly shaped by a combination of changes in atmospheric greenhouse gas levels, bottom water temperatures (assuming ice-free poles through our study period), and supply of solutes from terrestrial silicate weathering.

Multiple regression indicates four significant variables shaping $\mathrm{BN}_{\text {bioSiO}}$ flux: $\delta^{18} \mathrm{O}, p \mathrm{CO}_{2}, \delta^{13} \mathrm{C}$, and ${ }^{87} \mathrm{Sr} /{ }^{86} \mathrm{Sr}$. Except for $\delta^{13} \mathrm{C}$, this is consistent with the correlations discussed above. Notably, SWF was excluded by the multiple regression model. This is likely due to the high overall similarity in temporal trends displayed by $\mathrm{BN}_{\text {bio }} \mathrm{SiO}_{2}$ flux and SWF. The multiple regression model equation takes the form:

$$
{ }_{\text {bio }} \mathrm{SiO}_{2} \text { flux }=798.57-0.156 \times \delta^{18} \mathrm{O}-0.0008 \times p \mathrm{CO}_{2}-0.111 \times \delta^{13} \mathrm{C}-1126.58 \times{ }^{87} \mathrm{Sr} /{ }^{86} \mathrm{Sr}
$$

This model explains $\sim 71 \%$ of $\mathrm{BN}_{\text {bioSiO}}$ flux variance, with a standard error of estimation equal to 0.09 . We find that the model reproduces our calculated ${ }_{\text {bio }} \mathrm{SiO}_{2}$ flux values reasonably well (Fig. 2B). Thus, both the correlations and multiple regression suggest that $\mathrm{BN}$ bio $\mathrm{SiO}_{2}$ flux was shaped mostly by $\delta^{18} \mathrm{O}, p \mathrm{CO}_{2}$, and the supply of continental weathering products - all of which are related to the temperature-silicate weathering feedback. 

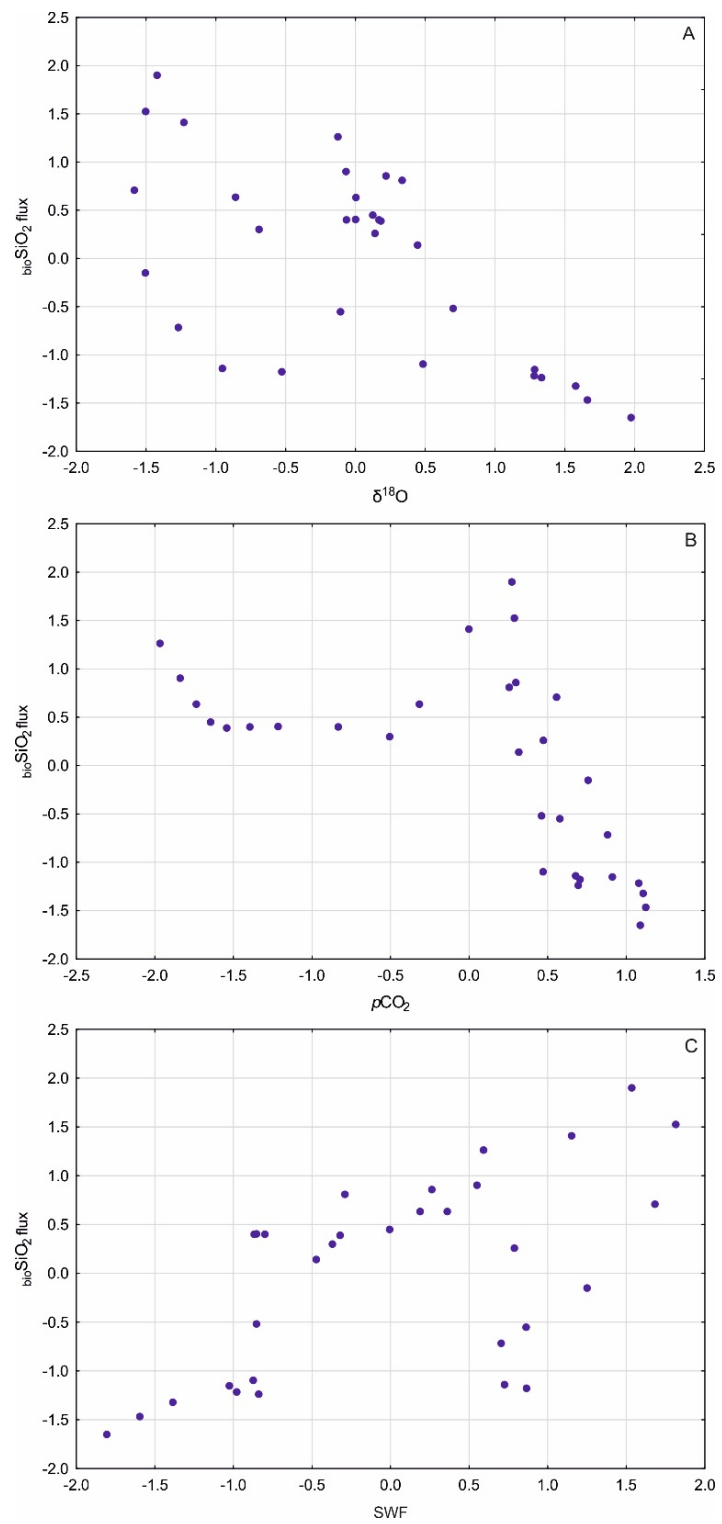

Figure 3. Correlation scatter plots for the three strongest statistical relationships identified in the present study: biogenic silica flux versus $\delta^{18} \mathrm{O}(\mathrm{A}), p \mathrm{CO}_{2}(\mathrm{~B})$, and silicate weathering flux (C). Abbreviations: bio $\mathrm{SiO}_{2}$ - biogenic silica; $\mathrm{SWF}-$ silicate weathering flux. Data sources indicated in the text.

\section{Discussion}

\subsection{Implications for paleocirculation}

The Blake Nose area is adjacent to the western margin of the North Atlantic subtropical gyre, which exerts a major control on nutrient availability in surface waters along the North American continental margin. Over the South 
Atlantic Bight region, encompassing the Blake Plateau, the key mechanism fuelling modern phytoplankton production is sub-mesoscale frontal eddies arising from meanders on the landward side of the Gulf Stream System (GSS; Richardson, 2001; Gula et al., 2015). Comparable cyclonic eddies of $<100 \mathrm{~km}$ diameter are observed also in other western boundary current (WBC) systems, which are generally viewed as oligotrophic settings (Roughan et al., 2017). These eddies are responsible for upward pumping of nutrients from sub-thermocline, nitrate-rich waters (Lee et al., 1991). Upwelled waters intrude onto the continental margin, and sustain rich biological production through the lifespan of an eddy (Roughan et al., 2017). Siliceous plankton production and export in the GSS is influenced by a number of factors, including Atlantic Meridional Overturning Circulation (AMOC) intensity, and the North Atlantic Oscillation, which together act to shift the GSS position relative to the North American seaboard on a decadal timescale (SanchezFranks and Zhang, 2015). Also the topography of the North American continental margin (Richardson, 2001) in conjunction with eustatic sea level variations exert a strong influence on the GSS path on long timescales, with features such as the Charleston Bump acting to deflect the jet trajectory toward the open ocean (Pinet et al., 1981; Gula et al., 2015).

A northeastward-flowing, wind- and Coriolis force-driven WBC likely operated in the North Atlantic at least since the Cretaceous (Gradstein and Sheridan, 1983), albeit at reduced strength relative to the modern before the final closure of the Central American Seaway (Montes et al., 2012). Given the overall stability of the western North Atlantic topography over the Cenozoic, occurrence of cyclonic frontal eddies were likely an inherent feature of the South

355 Atlantic Bight region throughout the Paleocene and Eocene. The semi-periodic fluctuations in $\mathrm{BN}_{\text {bio }} \mathrm{SiO}_{2}$ flux through time could therefore be also attributed to changes either in the mean GSS path (e.g., Wade and Kroon, 2002), or variations in sub-thermocline nutrient supply, which are largely dependent on vertical mixing of the ocean (Miskell et al., 1985; Moore et al., 2008) - or a combination of both processes.

Reconstructing intermediate- and deep-water circulation patterns in the North Atlantic through the early Cenozoic is more complex than reconstructing GSS history. Vahlenkamp et al. (2018) reviewed the existing perspectives on the Atlantic Ocean circulation through the Paleogene. $\varepsilon_{\mathrm{Nd}}$ reconstructions generally indicate a southern high-latitude source for the deep waters bathing the North American margin throughout the early-to-mid Paleogene (Thomas et al., 2003; Batenburg et al., 2018), although a Tethyan-sourced water mass is also hypothesized by some workers (Fontorbe et al., 2016; Vahlenkamp et al., 2018). At present, it is not known how a southern-sourced,

365 northward-flowing deep water mass may have affected nutrient availability and upwelling in the western North Atlantic, especially along continental margins. The high diatom:radiolarian (D:R) ratios (Witkowski et al., 2020b, for further discussion see below) and common occurrence of well-preserved epiphytic diatoms such as Arachnoidiscus (see Witkowski et al., 2020a) suggest that much of $\mathrm{BN}_{\text {bio }} \mathrm{SiO}_{2}$ fluxes through the Paleocene may be attributed to neritic production. Varying proportions of continental runoff-derived versus upwelled nutrient input could also be invoked to

370 explain the disparity in $\mathrm{biSiO}_{2}$ fluxes between the more proximal Site 1051 and the more distal Site 1050 through the Paleocene.

An intensely debated question in the early Paleogene deep-water circulation reconstructions is the timing of the onset of NCW flow - a precursor to quasi-modern deep-water circulation (Via and Thomas, 2006). North Atlantic $\delta^{13} \mathrm{C}$ records do not indicate major paleocirculation changes prior to the late Eocene ( $\sim 38 \mathrm{Ma}$; Katz et al., 2011; Borrelli et

375 al., 2014; Coxall et al., 2018), and numerous studies place the onset of AMOC either shortly prior to or following the EOT (Via and Thomas, 2006; Abelson and Erez, 2017; Coxall et al., 2018). 
https://doi.org/10.5194/cp-2021-50

Preprint. Discussion started: 12 May 2021

(c) Author(s) 2021. CC BY 4.0 License.
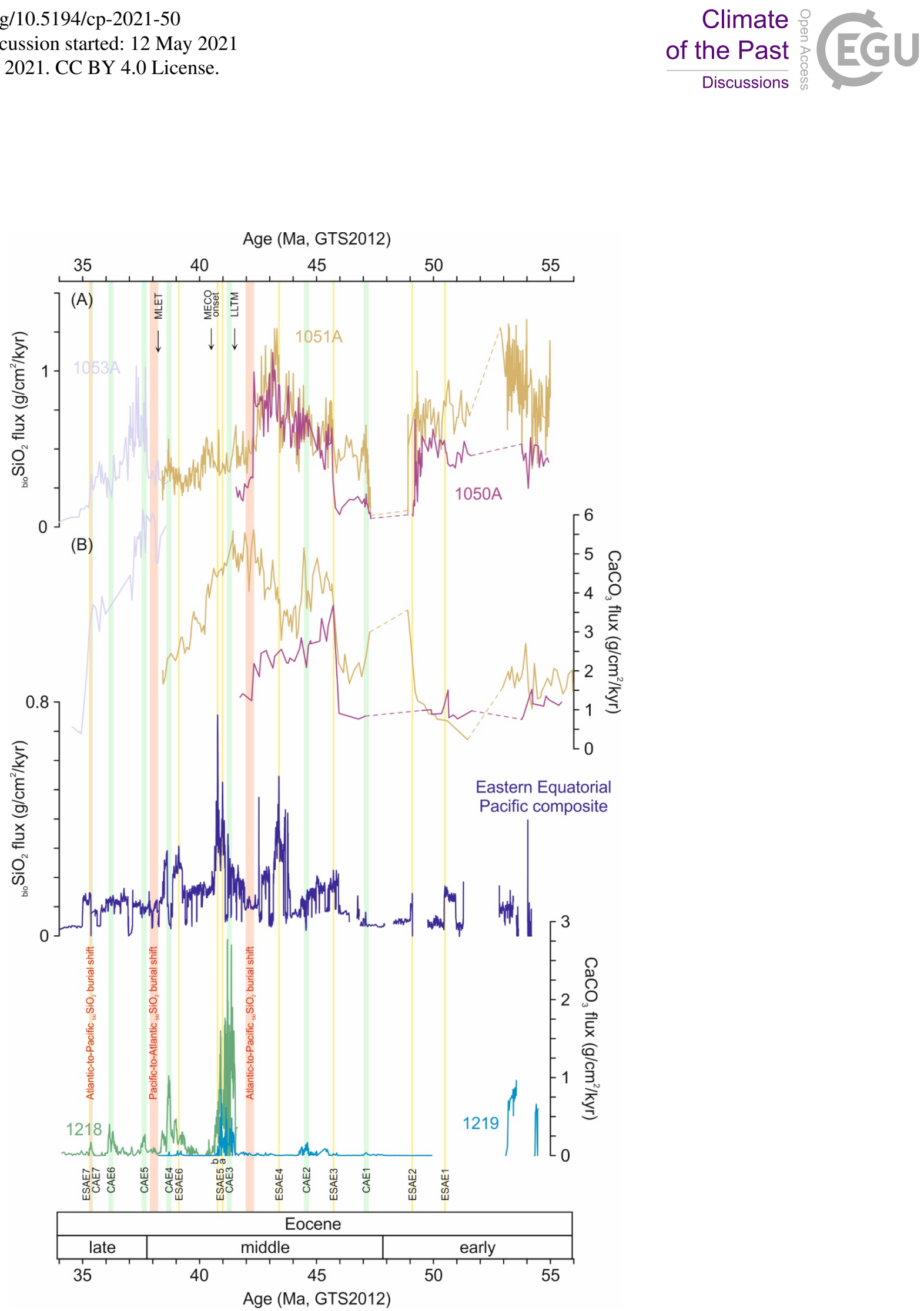

Figure 4. Eocene biogenic silica (A) and calcium carbonate (B) fluxes at Blake Nose sites plotted against biogenic silica (C) and calcium carbonate (D) fluxes at Eastern Equatorial Pacific sites. Blake Nose carbonate data from 
380 Shipboard Scientific Party (1998c,d,f). Eastern Equatorial Pacific data from Moore et al. (2008) and Lyle et al. (2005). Abbreviations: bioSiO 2 - biogenic silica; GTS2012 - Geologic Time Scale 2012, see Gradstein et al. (2012); MLET Middle-Late Eocene Turnover; LLTM - Late Lutetian Thermal Maximum; ESAE - Eocene Silica Accumulation Event; CAE - Carbonate Accumulation Event.

In contrast to the timing of NCW flow initiation indicated by isotopic proxy records, the onset of widespread drift deposition in the North Atlantic is documented much earlier, i.e., near the termination of the EECO ( 49 Ma; Hohbein et al., 2012; Boyle et al., 2017). This is also synchronous with ubiquitous deep-sea erosion coincident with the EMET (Aubry, 1995; Witkowski et al., 2020b), strongly suggesting that the onset of vigorous northern-sourced bottom current activity began at $49-47 \mathrm{Ma}$ (Vahlenkamp et al., 2018; Witkowski et al., 2020a). Following the EMET, the northward-flowing GSS and the invigorated deep WBC facilitated diapycnal mixing, which likely enhanced biological pump efficiency along continental margins of the western North Atlantic. This is consistent with a range of geochemical proxies, including thallium isotope $\left(\varepsilon^{205} \mathrm{Tl}\right)$ evidence for increased $\mathrm{C}_{\text {org }}$ burial from $\sim 50 \mathrm{Ma}$ (Nielsen et al., 2009) and with surface-to-deep $\delta^{13} \mathrm{C}$ gradients (Hilting et al., 2008). BN diatom assemblage data from Witkowski et al. (2020b) also support an oligotrophic regime over Blake Nose for the time period prior to and including the EECO, based on high

395 percentages of hemiauloids. Following the EECO (after $\sim 49 \mathrm{Ma}$ ), elevated percentages of diatom resting spores point to alternating, perhaps seasonal, periods of nutrient enrichment and depletion, in line with strong periodic upwelling of nutrients by means of Gulf Stream frontal eddies (Lee et al., 1991). This interpreted invigoration in ocean mixing led to a considerable increase in primary production during the early middle Eocene, as evidenced by a rapid increase in both $\mathrm{CaCO}_{3}$ and bio $\mathrm{SiO}_{2}$ fluxes at BN at $\sim 46 \mathrm{Ma}$ (Fig. 4A,B).

\subsection{Comparison to Eastern Equatorial Pacific bioSiO $\mathrm{Si}_{2}$ flux records}

The only published early Paleogene ${ }_{\text {bio }} \mathrm{SiO}_{2}$ flux record from another region of comparable duration to the $\mathrm{BN}$ composite record is that derived from Eastern Equatorial Pacific (EEP) cores (Moore et al., 2008). There are several important differences between the Atlantic and Pacific records (Fig. 4), including (1) contrasting proportions of diatoms in the BN versus EEP sediments; (2) the presence/absence of exported neritic material; and (3) a shorter time interval covered by the EEP record (Eocene only). Where the records overlap in time, however, there is a variable degree of coupling between $\mathrm{bio}_{2}$ flux records from $\mathrm{BN}$ and EEP.

High diatom:radiolarian (D:R) ratios in early-to-mid Paleogene sediments at BN were interpreted by Witkowski et al. (2020b) to indicate that bioSiO $\mathrm{Si}_{2}$ preserved was mostly of diatom origin. It is challenging, however, to provide a quantitative estimate of diatom versus radiolarian contribution to total $\mathrm{bioiO}_{2}$ at $\mathrm{BN}$, primarily because no published diatom valve weight data are available. In the modern oceans, radiolarian tests are on average an order of magnitude heavier than diatom valves (with differences in fact ranging over several orders of magnitude; Lisitzin, 1971). Assuming a 10:1 radiolarian to diatom skeleton weight ratio for the early Paleogene, and using an average radiolarian test weight of $0.225 \mu \mathrm{g}$ consistent with the range of values displayed by the oldest materials included in Moore (1969), we make a rough estimate of diatom versus radiolarian contribution to total $\mathrm{BN}_{\text {bio }} \mathrm{SiO}_{2}$ based on

415 quantitative siliceous microfossil counts of Witkowski et al. (2020b). As other siliceous plankton groups are sparse in BN siliceous microfossil assemblages (Witkowski et al., 2020b), and likely contribute little bio $\mathrm{SiO}_{2}$ to sediments (Lisitzin, 1971), we exclude the relatively minor contributions of silicoflagellates, siliceous dinoflagellates, and 
chrysophycean cysts from the calculations. These rough approximations indicate a mean diatom contribution of $\sim 35.7 \%$ to the total biogenic silica content at BN (Fig. S6 in the online Supplementary Materials), with the highest values observed for the early and middle Paleocene, consistent with the D:R ratios ranging as high as $>200$ reported by Witkowski et al. (2020b). Given that diatom valves are less resistant to dissolution than radiolarian tests, the contribution of diatoms to total bio $\mathrm{SiO}_{2}$ in early Paleogene sediments at $\mathrm{BN}$ is likely underestimated due to selective dissolution. A final caveat on these considerations is that they disregard ${ }_{b i o} \mathrm{SiO}_{2}$ comprised in sponge spicules, for which no quantitative data are available from the BN cores.

In contrast, Moore et al. (2008) refer to the near-absence of diatoms in the early Paleogene EEP cores as an "enigma". Although Moore et al. (2008) do not specify whether or not this observation is based on sieved residues, (thereby potentially missing diatom in the smaller sediment fractions), other Paleogene diatom reports from pelagic low-latitude Pacific sites corroborate this view (e.g., Fenner, 1984). We propose that the reason for this difference in diatom abundance in sediments between BN and EEP is twofold. Firstly, most early Paleogene diatom occurrences in

430 the Atlantic are in marginal settings (Witkowski et al., 2020b), where at least part of the preserved diatom assemblage may originate from offshore export of neritic plankton. Secondly, the radiolarian-rich Pacific sites mostly represent pelagic deposition at water depths of $\sim 4-5 \mathrm{~km}$. Diatom dissolution is facilitated by longer times in transit through the water column. Also, Al content, which is known to buffer diatom preservation in sediments (DeMaster, 2014), is lower in pelagic sediments relative to the continental margins. The $\mathrm{BN}$ and EEP records also differ in the magnitude of bio $\mathrm{SiO}_{2}$

435 fluxes: as discussed in Witkowski et al. $(2014 ; 2020$ b), the BN area received large volumes of neritic plankton through the early Paleogene, that underwent offshore export likely by means of frontal eddies, and the resultant bioSiO $\mathrm{Sluxes}_{2}$ are high. The pelagic EEP sites likely record only local, pelagic production and deposition, with low bio $\mathrm{SiO}_{2}$ fluxes relative to the $\mathrm{BN}$.

Eocene EEP sediment accumulation rates are generally low, punctuated by a series of elevated flux events termed ESAEs (Eocene Silica Accumulation Events - see Moore et al., 2008) and CAEs (Carbonate Accumulation Events - see Lyle et al., 2005) (Fig. 4C-D). Between $\sim 55$ and $46 \mathrm{Ma}$, bioSiO ${ }_{2}$ fluxes in the EEP are low, and appear decoupled from the $\mathrm{BN}$ records. ESAE 3 at $\sim 45.8 \mathrm{Ma}$ marks the onset of enhanced bioSiO 2 flux in the EEP (Fig. 4C). Notably, ESAE 3 appears to be age-equivalent to a prominent increase in $\mathrm{BN}_{\text {bio }} \mathrm{SiO}_{2}$ and $\mathrm{CaCO}_{3}$ fluxes (Fig. $4 \mathrm{~A}$ vs $\mathrm{C}$ ). ESAE 4 at $\sim 44.3 \mathrm{Ma}$ is correlative to the peak in middle Eocene bioSiO $\mathrm{Si}_{2}$ flux at $\mathrm{BN}$ (Fig. 4A vs C). Following ESAE 4, 445 however, trends in bio $\mathrm{SiO}_{2}$ flux again become decoupled between the two regions. bio $\mathrm{SiO}_{2}$ fluxes diminish at $\mathrm{BN}$ between $\sim 42$ and $38 \mathrm{Ma}$, and a concomitant reduction is observed in the geographic distribution of siliceous microfossils in the Atlantic Ocean (Witkowski et al., 2020b) (Fig. 4A vs C). Thus, reduced ${ }_{\text {bio }} \mathrm{SiO}_{2}$ accumulation between $\sim 42$ and $38 \mathrm{Ma}$ is not a local phenomenon restricted to the $\mathrm{BN}$ area, but instead it is likely indicative of a major change in nutrient supply or paleocirculation that affected the entire Atlantic basin. In contrast, this late middle Eocene 450 period of low bioSiO $\mathrm{Si}_{2}$ flux at $\mathrm{BN}$ precisely corresponds to an interval of elevated bioSiO 2 fluxes in the EEP (Fig. 4A vs C), including the bimodal ESAE 5, which represents the peak in the Eocene $\mathrm{EEP}_{\text {bio }} \mathrm{SiO}_{2}$ accumulation at $\sim 41 \mathrm{Ma}$.

Near the end of the middle Eocene, ESAE 6 is abruptly terminated at $\sim 38.5 \mathrm{Ma}$, concomitant with a major radiolarian turnover at EEP sites (Moore et al., 2008). A similar episode of accelerated turnover in radiolarians has been identified at $\sim 38.25$ at BN (Kamikuri and Wade, 2012; Newsam et al., 2017), but in conjunction with a rapid rise in

455 bio $\mathrm{SiO}_{2}$ flux levels. ESAEs 7 and 8 in the EEP are minor events at $\sim 35$ and $\sim 34 \mathrm{Ma}$, respectively, and no age-equivalent events are observed in the $\mathrm{BN}$ bio $\mathrm{SiO}_{2}$ flux record. We interpret the decoupling between $\mathrm{BN}$ and $\mathrm{EEP}_{\text {bio }} \mathrm{SiO}_{2}$ flux 
records after $\sim 42 \mathrm{Ma}$ as a series of inter-basin bioSiO 2 accumulation shifts (Fig. 4A vs C), likely associated with deepwater circulation changes (Berger, 1970) affecting the seabed preservation of bio $\mathrm{SiO}_{2}$.

Diminished $\mathrm{BN}_{\text {bio }} \mathrm{SiO}_{2}$ fluxes indicate lower nutrient supply from $\sim 42$ to $38 \mathrm{Ma}$, i.e., through the interval spanning both Late Lutetian Thermal Maximum (LLTM, 41.5 Ma; Westerhold et al., 2018b) and Middle Eocene Climatic Optimum (MECO, 40 Ma; Bohaty et al., 2009; Henehan et al., 2020). Modern field observations indicate that diminished supply of nutrients to the GSS may result from weakened AMOC. Witkowski et al. (2020b) demonstrate a reduced geographic range of biosiliceous accumulation in the Atlantic between $\sim 42$ and $38 \mathrm{Ma}$, which is also consistent with a diminished nutrient supply. Accordingly, we propose a period of potentially weakened AMOC spanning both the LLTM and MECO events.

The Pacific-to-Atlantic bioSiO $\mathrm{Sil}_{2}$ flux shift at $\sim 38 \mathrm{Ma}$ coincides with increased rates of radiolarian turnover and planktonic foraminiferal extinction designated MLET by Kamikuri and Wade (2012). More importantly, however, the abrupt increase in bio $\mathrm{SiO}_{2}$ flux at Site 1053 took place in conjunction with shifts in benthic foraminiferal $\delta^{13} \mathrm{C}$ (Katz et al., 2011; Borrelli et al., 2014; Coxall et al., 2018) interpreted to mark the onset of NCW export.

Thus, the repeated shifts in bio $\mathrm{SiO}_{2}$ fluxes between NW Atlantic and EEP through the late middle and late Eocene suggest that the 'lagoonal' Atlantic (=carbonate burial-favoring) versus 'estuarine' Pacific ( $=\mathrm{SiO}_{2}$ burialfavoring) circulation pattern proposed by Berger (1970) was established in the lead-up to LLTM and temporarily reversed at the MLET before its final reestablishment shortly before the EOT. These shifts were likely driven by changes in deep-sea circulation patterns. Importantly, however, this interpretation implies that the two scenarios for

475 NCW export inception (at EOT: Borrelli et al., 2014; and Coxall et al., 2018; versus at the end of the EECO: Hohbein et al., 2012; Boyle et al., 2017; and Vahlenkamp et al., 2018) are not mutually exclusive. The patterns in Atlantic to Pacific bioSiO $\mathrm{Sl}_{2}$ flux fractionation outlined above suggest a $\sim 4$ myr period of the early AMOC disruption spanning the last of the Eocene greenhouse warming events, i.e., LLTM and MECO. Moreover, the evidence supporting NCW inception in the late Eocene or early Oligocene may in fact point to a reinvigoration of AMOC flow following a period of weakened overturning circulation between 42 and $38 \mathrm{Ma}$.

\subsection{Implications for the silicate weathering feedback operation mode}

The silicate weathering feedback has been proposed as the key mechanism for keeping the Earth surface temperatures within a habitable range over $10^{5}-10^{6}$ yr-timescales (Walker et al., 1981; Kasting, 2019). By consuming atmospheric $\mathrm{CO}_{2}$ and releasing alkalinity and dissolved silicon (Penman, 2016), this feedback mechanism also influences key biogeochemical cycles within the ocean-atmosphere system, resulting in a tight coupling between the marine carbon and silicon cycles (Tréguer and De La Rocha, 2013). In recent years, however, the operation of the silicate weathering feedback through the Cenozoic has been disputed, with a special focus on whether the strength of the link between climate and continental weathering varies through time (Caves et al., 2016; van der Ploeg et al., 2018). One point of disagreement concerns the early Paleogene. In the traditional view (hereafter "constant feedback strength scenario"), which assumes a linear relationship between global temperature change and weathering, the early Paleogene greenhouse climates should facilitate increased rates of chemical weathering on land directly proportional to the magnitude of $\mathrm{CO}_{2}$-driven warming (e.g., Misra and Froelich, 2012; Sluijs et al., 2013; Penman, 2016). An emerging alternative view (hereafter "variable feedback strength scenario") is that during the Eocene the feedback strength was at a minimum level (Caves et al., 2016; van der Ploeg et al., 2018), with lowered silicate weathering intensity (and, hence, 
reduced weathering feedback strength) promoting high $p \mathrm{CO}_{2}$ levels and a warm climate (Misra and Froelich, 2012). Assuming that the early-to-mid Paleogene silicon cycle already operated in its present-day form (Fontorbe et al., 2016; Conley et al., 2017), these scenarios should lead to different marine bioSiO $\mathrm{S}_{2}$ flux responses. In the constant feedback strength scenario, bio $\mathrm{SiO}_{2}$ production and burial would be expected to peak during the EECO, i.e., the warmest period of the Cenozoic era (e.g., Kirtland-Turner et al., 2014; Cramwinckel et al., 2018; Westerhold et al., 2018a). In the variable feedback strength scenario, the silicate weathering flux should decrease through the Eocene (Caves et al., 2016), leading to a decrease in dissolved silicon supply and ${ }_{b i o} \mathrm{SiO}_{2}$ burial.

In the $\mathrm{BN}$ composite, both $\%{ }_{\text {bio }} \mathrm{SiO}_{2}$ and ${ }_{\text {bio }} \mathrm{SiO}_{2}$ flux values are high in the lead-up to the $\mathrm{EECO}(\sim 55$ through $53.5 \mathrm{Ma})$ and considerably lower in the final phases of the EECO ( $\sim 51$ through $49 \mathrm{Ma})$. The hiatus spanning $\sim 53.5$ through $52 \mathrm{Ma}$, however, precludes any definitive conclusions on the behavior of the silicate weathering feedback through the entire EECO period, particularly with regard to the constant versus variable strength of its link to climate. Importantly, however, bioSiO 2 flux values through the middle Eocene are consistently higher than background Paleocene-early Eocene values both in the Atlantic and in the Pacific (see also Moore et al., 2008, and Section 4.2), which cannot be easily reconciled with the linear feedback strength scenario. Thus, it appears that long-term trends in ${ }_{\text {bio }} \mathrm{SiO}_{2}$ flux are more consistent with the variable feedback strength scenario, suggesting that the strength of the link

510 between climate and terrestrial silicate weathering may indeed be variable through time. Secondly, the high levels of ${ }_{\text {bio }} \mathrm{SiO}_{2}$ flux through the middle Eocene cooling (Fig. 2B) point to enhanced nutrient supply from invigorated ocean circulation as a major control on ${ }_{b i} \mathrm{SiO}_{2}$ flux in the younger part of our study period.

\section{Conclusions}

Deep-water temperatures, atmospheric greenhouse gas levels, and continental weathering are identified as the

515 main drivers of $\mathrm{bioSiO}_{2}$ flux through the Paleocene and Eocene at Blake Nose in the western North Atlantic Ocean. Variations in bioSiO 2 fluxes support an early export of $\mathrm{NCW}$, but also suggest a period of disruption to the early form of AMOC between 42 and $38 \mathrm{Ma}$, as suggested by the Atlantic to Pacific bioSiO$_{2}$ flux fractionation. Additionally, BN ${ }_{\text {bio }} \mathrm{SiO}_{2}$ fluxes indicate that the long-term behavior of the silicate weathering thermostat conforms to the variable rather than constant weathering-climate feedback strength scenario.

Code/data availability: all data generated in this study is included in the online Supplementary Materials.

Competing interests: The authors declare that they have no conflict of interest.

Author contribution: JW, SMB and DEP designed the study. JW, KB, BSW EM performed sampling and analyses. EM performed the statistical analysis. All authors participated in interpreting the data. JW prepared the manuscript, with input from all co-authors.

\section{Acknowledgements}

This study was supported by National Science Center (Poland) grant no. 2014/13/B/ST10/02988 to JW. Walter Hale, Holger Kuhlmann and the IODP Bremen Core Repository staff are thanked for efficient handling of multiple sample requests. Annette Olivarez Lyle, Mitchell Lyle, and Dorota Burska are thanked for advice on using the alkaline leaching method. We are indebted to Julita Tomkowiak, Agnieszka Ławecka, Adrianna Szaruga, Adrianna Januszkiewicz and Zofia Stachowska for assistance in sample treatment and spectrophotometric analyses. 


\section{References}

Abelson, M. and Erez, J.: The onset of modern-like Atlantic meridional overturning circulation at the Eocene-Oligocene transition: evidence, causes, and possible implications for global cooling, Geochem. Geophys., 18, 2177-2199, https://doi.org/10.1002/2017GC006826, 2017.

Anagnostou, E., John, E.H., Edgar, K.M., Foster, G.L., Ridgwell, A., Inglis, G.N., Pancost, R.D., Lunt, D.J., and Pearson, P.N.: Changing atmospheric $\mathrm{CO}_{2}$ concentration was the primary driver of early Cenozoic climate, Nature, 533, 380-384, https://doi.org/10.1038/nature17423, 2016.

Aubry, M.-P: From chronology to stratigraphy: interpreting the lower and middle Eocene stratigraphic record in the Atlantic Ocean, in: Geochronology, Time Scales, and Global Stratigraphic Correlation, edited by: Berggren, W.A., Kent, D.V., Aubry, M.-P., and Hardenbol, J., SEPM Special Publication, 54, 213-274, https://doi.org/10.2110/pec.95.04.0213, 1995.

Barron, J.A., Stickley, C.E., and Bukry, D.: Paleoceanographic, and paleoclimatic constraints on the global Eocene diatom and silicoflagellate record, Palaeogeogr. Palaeoclimatol. Palaeoecol., 422, 85-100, https://doi.org/10.1016/j.palaeo.2015.01.015, 2015.

545 Batenburg, S.J., Voigt, S., Friedrich, O., Osborne, A.H., Bornemann, A., Klein, T., Péréz-Díaz, L., and Frank, M.: Major intensification of Atlantic overturning circulation at the onset of Paleogene greenhouse warmth, Nat. Commun., 9, 4954, https://doi.org/10.1038/s41467-018-07457-7, 2018.

Berger, W.H.: Biogenous Deep-Sea Sediments: Fractionation by Deep-Sea Circulation, Geol. Soc. Am. Bull., 81, 1385 1402, https://doi.org/10.1130/0016-7606(1970)81[1385:BDSFBD]2.0.CO;2, 1970.

550 Bohaty, S. M., Zachos, J. C., Florindo, F., and Delaney, M. L.: Coupled greenhouse warming and deep-sea acidification in the middle Eocene, Paleoceanography, 24, PA2207, https://doi.org/10.1029/2008PA001676, 2009.

Boyle, R., Romans, B. W., Tucholke, B. E., Norris, R. D., Swift, S. A., and Sexton, F.: Cenozoic North Atlantic deep circulation history recorded in contourite drifts, offshore Newfoundland, Canada, Mar. Geol., 385, 185-203, https://doi.org/10.1016/j.margeo.2016.12.014, 2017.

555 Borrelli, C., Cramer, B.S., and Katz, M.E.: Bipolar Atlantic deepwater circulation in the middle-late Eocene: effects of Southern Ocean gateway openings, Paleoceanography, 29, 308-327, https://doi.org/10.1002/2012PA002444, 2009.

Caves, J.K., Jost, A.B., Lau, K.V., and Maher, K.: Cenozoic carbon cycle imbalances and a variable weathering feedback, Earth Planet. Sci. Lett., 450, 152-163, https://doi.org/10.1016/j.eps1.2016.06.035, 2016.

Cermeño, P., Falkowski, P.G., Romero, O.E., Schaller, M.F., and Vallina, S.M.: Continental erosion and the Cenozoic

560 rise of marine diatoms, Proc. Natl. Acad. Sci. U.S.A., 112, 4239-4244, https://doi.org/10.1073/pnas.1412883112, 2015. Cleveland, W. S., Grosse, E., and Shyu, W. M.: Local regression models, in: Statistical Models in S, edited by: Chambers, J.M. and Hastie, T.J., Chapman \& Hall, London, United Kingdom, 309-376, 1992.

Conley, D.J., Frings, P.J., Fontorbe, G., Clymans, and W., Stadmark, J.: Biosilicification Drives a Decline of Dissolved Si in the Oceans through Geologic Time: Front. Mar. Sci., 4, 397, https://doi.org/10.3389/fmars.2017.00397, 2017.

565 Coxall, H.K., Huck, C.E., Huber, M., Lear, C.H., Legarda-Lisarri, A., O’Regan, M., Sliwińska, K.K., van de Flierdt, T., de Boer, A.M., Zachos, J.C., and Backman, J.: Export of nutrient rich Northern Component Water preceded early Oligocene Antarctic glaciation, Nat. Geosci., 11, 190-196, https://doi.org/10.1038/s41561-018-0069-9, 2018. Cramer, B.S., Toggweiler, J.R., Wright, J.D., Katz, M.E., and Miller, K.G.: Ocean overturning since the Late Cretaceous: Inferences from a new benthic foraminiferal isotope compilation, Paleoceanography, 24, PA4216, https://doi.org/10.1029/2008PA001683, 2009. 
Cramwinckel, M.J., Huber, M., Kocken, I.J., Agnini, C., Bijl, P.K., Bohaty, S.M., Frieling, J., Goldner, A., Hilgen, F.J., Kip, E.L., Peterse, F., van der Ploeg, R., Röhl, U., Schouten, S., and Sluijs, A.: Synchronous tropical and polar temperature evolution in the Eocene, Nature, 559, 382-386, https://doi.org/10.1038/s41586-018-0272-2, 2018. D'haenens, S., Bornemann, A., Claeys, P., Röhl, U., Steurbaut, E., and Speijer, R. P.: A transient deep-sea circulation switch during Eocene Thermal Maximum 2, Paleoceanography, 29, 370- 388, https://doi.org/10.1002/2013PA002567, 2014.

DeMaster, D.J.: The diagenesis of biogenic silica: chemical transformations occurring in the water column, seabed, and crust, in: Treatise on Geochemistry, 2nd Edition, edited by: Holland, H.D. and Turekian, K.K., Elsevier, Amsterdam, The Netherlands, 9, 103-111, https://doi.org/10.1016/B978-0-08-095975-7.00704-X, 2014.

580 Diekmann, B., Kuhn, G., Gersonde, R., and Mackensen, A.: Middle Eocene to early Miocene environmental changes in the sub-Antarctic Southern Ocean: evidence from biogenic and terrigenous depositional patterns at ODP Site 1090, Glob. Planet. Change, 40, 295-313, https://doi.org/10.1016/j.gloplacha.2003.09.001, 2004.

Diester-Haass, L.: Middle Eocene to early Oligocene paleoceanography of the Antarctic Ocean (Maud Rise,ODP Leg 13, Site 689): change from a low to a high productivity ocean, Palaeogeogr. Palaeoclimatol. Palaeoecol., 113, 311-334, 585 https://doi.org/10.1016/0031-0182(95)00067-V, 1995.

Egan, K.E., Rickaby, R.E.M., Hendry, K.R., and Halliday, A.N.: Opening the gateways for diatoms primes Earth for Antarctic glaciation, Earth Planet. Sci. Lett., 375, 34-43, https://doi.org/ 10.1016/j.epsl.2013.04.030, 2013.

Fenner, J.: Middle Eocene to Oligocene planktonic diatom stratigraphy from deep sea drilling sites in the South Atlantic, Equatorial Pacific, and Indian oceans, Init. Repts DSDP, 75, 1245-1271,

590 https://doi.org/10.2973/dsdp.proc.75.149.1984, 1984.

Fenner, J.: Taxonomy, stratigraphy, and paleoceanographic implications of Paleocene diatoms, Proc. ODP, Sci. Res., 114, 123-154, https://doi.org/10.2973/odp.proc.sr.114.137.1991, 1991.

Fontorbe, G., Frings, P.J., De La Rocha, C.L., Hendry, K.R., and Conley, D.J.: A silicon depleted North Atlantic since the Palaeogene: evidence from sponge and radiolarian silicon isotopes, Earth Planet. Sci. Lett., 453, 67-77,

595 https://doi.org/10.1016/j.epsl.2016.08.006, 2016.

Fontorbe, G., Frings, P.J., De La Rocha, C.L., Hendry, K.R., and Conley, D.J.: Constraints on Earth system functioning at the Paleocene-Eocene Thermal Maximum from the marine silicon cycle, Paleoceanography and Paleoclimatology, 35, e2020PA003873, https://doi.org/10.1029/2020PA003873, 2020.

Foster, G., Royer, D., and Lunt, D., Future climate forcing potentially without precedent in the last 420 million years,

600 Nat. Commun., 8, 14845, https://doi.org/10.1038/ncomms14845, 2017.

Frings, P.: Revisiting the dissolution of biogenic Si in marine sediments: a key term in the ocean Si budget, Acta Geochim., 36, 429-432, https://doi.org/10.1007/s11631-017-0183-1, 2017.

Froelich, F. and Misra, S.: Was the late Paleocene-early Eocene hot because Earth was flat? An ocean lithium isotope view of mountain building, continental weathering, carbon dioxide, and Earth's Cenozoic climate, Oceanography, 27,

605 36-49, https://doi.org/10.5670/oceanog.2014.06, 2015.

Gombos, Jr., A.M.: Early and Middle Eocene diatom evolutionary events, Bacillaria, 5, 225-243, 1982.

Gradstein, F.M., and Sheridan, R.E.: On the Jurassic Atlantic Ocean and a synthesis of results of DSDP Project Leg 76: Init. Repts DSDP, 76, 913-943, https://doi.org/10.2973/dsdp.proc.76.144.1983, 1983.

Gradstein, F.M., Ogg, J.G., Schmitz, M.D., and Ogg, G.M. (editors): The Geologic Time Scale 2012, Elsevier,

610 Amsterdam, The Netherlands, 2 vols, 1144 pp., https://doi.org/10.1016/C2011-1-08249-8, 2012. 
Gula, J., Molemaker, M.J., and McWilliams, J.C.: Gulf Stream Dynamics along the Southeastern U.S. Seaboard, J. Phys. Oceanogr., 45, 690-715, https://doi.org/10.1175/JPO-D-14-0154.1, 2015.

Gula, J., Molemaker, M.J., and McWilliams, J.C.: Submesoscale Dynamics of a Gulf Stream Frontal Eddy in the South Atlantic Bight, J. Phys. Oceanogr , 46, 305-325, https://doi.org/10.1175/JPO-D-14-0258.1, 2016.

615 Handoh, I.C., Bigg, G.R., and Jones, E.J.W.: Evolution of upwelling in the Atlantic Ocean basin, Palaeogeogr. Palaeoclimatol. Palaeoecol., 202, 31-58, https://doi.org/10.1016/S0031-0182(03)00571-6, 2003.

Henehan, M.J., Edgar, K.M., Foster, G.L., Penman, D.E., Hull, P.M., Greenop, R., Anagnostou, E. and Pearson, P.N.: Revisiting the Middle Eocene Climatic Optimum 'Carbon Cycle Conundrum 'with new estimates of atmospheric $\mathrm{pCO}_{2}$ from boron isotopes, Paleoceanography and Paleoclimatology, 35, e2019PA003713,

620 https://doi.org/10.1029/2019PA003713, 2020.

Hilting, A. K., Kump, L. R., and Bralower, T. J.: Variations in the oceanic vertical carbon isotope gradient and their implications for the Paleocene-Eocene biological pump, Paleoceanography, 23, PA3222, https://doi.org/10.1029/2007PA001458, 2008.

Hohbein, M.W., Sexton, P.F., and Cartwright, J.A.: Onset of North Atlantic Deep Water production coincident with 625 inception of the Cenozoic global cooling trend, Geology, 40, 255-258, https://doi.org/10.1130/G32461.1, 2012. Hollis, C.J.: Data report: siliceous microfossil abundance in IODP Expedition 342 sediments, Proc. IODP, 342, 1-16 (Online), https://doi.org/10.2204/iodp.proc.342.201.2017, 2014.

Iwasaki, S., Takahashi, K., Ogawa, Y., Uehara, S., and Vogt, C.: Alkaline leaching characteristics of biogenic opal in Eocene sediments from the central Arctic Ocean: a case study in the ACEX cores, J. Oceanogr., 70, 241-249,

630 https://doi.org/10.1007/s10872-014-0227-7, 2014.

Kamikuri, S.-I. and Wade, B.S.: Radiolarian magnetobiochronology and faunal turnover across the middle/late Eocene boundary at Ocean Drilling Program Site 1052 in the western North Atlantic Ocean, Mar. Micropaleontol., 88-89, 4153, https://doi.org/10.1016/j.marmicro.2012.03.001, 2012.

Kasting, J.F.: The Goldilocks Planet? How Silicate Weathering Maintains Earth “Just Right”, Elements, 15, 235-240,

635 https://doi.org/10.2138/gselements.15.4.235, 2019.

Katz, M.E., Cramer, B.S., Toggweiler, J.R., Esmay, G., Liu, Ch., Miller, K.G., Rosenthal, Y., Wade, B.S., and Wright, J.D.: Impact of Antarctic Circumpolar Current Development on Late Paleogene Ocean Structure, Science, 332, 10761079, https://doi.org/10.1126/science.1202122, 2011.

Kirtland-Turner, S., Sexton, P.F., Charles, C.D., and Norris, R.D.: Persistence of carbon release events through the peak

640 of early Eocene global warmth, Nat. Geosci., 7, 748-751, https://doi.org/10.1038/ngeo2240, 2014.

Klemm, V., Levasseur, S., Frank, M., Hein, J.R., and Halliday, A.N.: Osmium isotope stratigraphy of a marine ferromanganese crust, Earth Planet. Sci. Lett., 238, 42-48, https://doi.org/10.1016/j.eps1.2005.07.016, 2005.

Lazarus, D., Barron, J.A., Renaudie, J., Diver, P., and Türke, A.: Cenozoic Planktonic Marine Diatom Diversity and Correlation to Climate Change, PLOS ONE, 9, e84857, https://doi.org/10.1371/journal.pone.0084857, 2014.

645 Lee, T.N., Yoder, J.A., and Atkinson, L.P.: Gulf Stream Frontal Eddy Influence on Productivity of the Southeast U.S. Continental Shelf, J. Geophys. Res., 96, 22 191-22 205, https://doi.org/10.1029/91JC02450, 1991.

Lisitzin, A.P.: Distribution of siliceous microfossils in suspension and in bottom sediments, in: The Micropalaeontology of Oceans, edited by Funnell, B.M. and Riedel, W.R., Cambridge University Press, Cambridge, United Kingdom, 173$196,1971$. 
Lyle, M., Olivarez Lyle, A., Backman, J., and Tripati, A.: Biogenic Sedimentation in the Eocene Equatorial PacificThe Stuttering Greenhouse and Eocene Carbonate Compensation Depth, Proc. ODP, Sci. Res., 199, 1-35 (Online), https://doi.org/10.2973/odp.proc.sr.199.219.2005, 2005.

Malviya, S., Scalco, E., Audic, S., Vincent, F., Veluchamy, A., Poulain, J., Wincker, P., Iudicone, D., de Vargas, C., Bittner, L., Zingone, A., and Bowler, C.: Insights into global diatom distribution and diversity in the world's ocean, Proc. Natl. Acad. Sci. U.S.A., 113, 1516-1525, https://doi.org/10.1073/pnas.1509523113, 2016.

Miller, K.G., Browning, J.V., Schmelz, W.J., Kopp, R.E., Mountain, G.S., and Wright, J.D.: Cenozoic sea-level and cryospheric evolution from deep-sea geochemical and concinental margin records: Sci. Adv., 6, eaaz1346, https://doi.org/10.1126/sciadv.aaz1346, 2020.

Miskell, K.J., Brass, G.W., and Harrison, C.G.A.: Global patterns in opal deposition from Late Cretaceous to Late Miocene, AAPG Bull., 69, 996-1012, https://doi.org/10.1306/AD462B41-16F7-11D7-8645000102C1865D, 1985. Misra, S. and Froelich, N., Lithium isotope history of Cenozoic seawater: changes in silicate weathering and reverse weathering, Science, 335, 818-823, https://doi.org/10.1126/science.1214697, 2012.

Montes, C., Cardona, A., McFadden, R., Morón, S.E., Silva, C.A., Restrepo-Moreno, S., Ramírez, D.A., Hoyos, N., Wilson, J., Farris, D., Bayona, G.A., Jaramillo, C.A., Valencia, V., Bryan, J., and Flores, J.A.: Evidence for middle

665 Eocene and younger land emergence in central Panama: Implications for Isthmus closure, Geol. Soc. Am. Bull., 124, 780-799, https://doi.org/10.1130/B30528.1, 2012.

Moore, T.C., Jr.: Radiolaria: change in skeletal weight and resistance to solution, Geol. Soc. Am. Bull., 80, 2103-2108, https://doi.org/10.1130/0016-7606(1969)80[2103:RCISWA]2.0.CO;2, 1969.

Moore, T.C., Jr., Jarrard, R.D., Olivarez Lyle, A., and Lyle, M.: Eocene biogenic silica accumulation rates at the Pacific

670 equatorial divergence zone, Paleoceanography, 23, PA220, https://doi.org/10.1029/2007PA001514, 2008.

Muttoni, G. and Kent, D.V.: Widespread formation of cherts during the early Eocene climate optimum, Palaeogeogr. Palaeoclimatol. Palaeoecol., 253, 348-362, https://doi.org/10.1016/j.palaeo.2007.06.008, 2007.

Newsam, C., Bown, R., Wade, B. S., and Jones, H. L.: Muted calcareous nannoplankton response at the Middle/Late Eocene Turnover event in the western North Atlantic Ocean, Newsl. Stratig., 50, 297-309,

675 https://doi.org/10.1127/nos/2016/0306, 2017.

Nielsen, S.G., Mar-Gerrison, S., Gannoun, A., LaRowe, D., Klemm, V., Halliday, A.N., Burton, K.W., and Hein, J.R.: Thallium isotope evidence for a permanent increase in marine organic carbon export in the early Eocene, Earth Planet. Sci. Lett., 278, 397-307, https://doi.org/10.1016/j.epsl.2008.12.010, 2009.

Nishimura, A.: Paleocene radiolarian biostratigraphy in the northwest Atlantic at Site 384, Leg 43, of the Deep Sea

680 Drilling Project, Micropaleontology, 38, 317-362, 1992.

Ogg, J.G. and Bardot, L.: Aptian through Eocene magnetostratigraphic correlation of the Blake Nose Transect (Leg 171B), Florida Continental Margin, Proc. ODP, Sci. Res., 171B, 1-58 (Online),

https://doi.org/10.2973/odp.proc.sr.171B.104.2001, 2001.

Ocean Drilling Stratigraphic Network: https://www.odsn.de/, last access 15 April 2021.

685 Olivarez Lyle, A. and Lyle, M.: Determination of biogenic opal in pelagic marine sediments: a simple method revisited, Proc. ODP, Init. Repts., 199, 1-21 (Online), https://doi.org/10.2973/odp.proc.ir.199.106.2002, 2002.

Oreshkina, T.V. and Aleksandrova, G.N.: Terminal paleocene of the Volga middle reaches: Biostratigraphy and paleosettings, Stratigr. Geol. Correl., 15, 206-230, https://doi.org/10.1134/S0869593807020062, 2007.

Penman, D.: Silicate weathering and North Atlantic silica burial during the Paleocene-Eocene Thermal Maximum, 
Penman, D.E., Caves Rugenstein, J.K., Ibarra, D.E., and Winnick, M.J.: Silicate weathering as a feedback and forcing in Earth's climate and carbon cycle, Earth-Sci. Rev., 209, 103298, https://doi.org/10.1016/j.earscirev.2020.103298, 2020.

Penman, D., Keller, A., D'haenens, S., Turner, S.K., and Hull, P.M.: Atlantic Deep-Sea Cherts Associated With Eocene Hyperthermal Events, Paleoceanography and Paleoclimatology, 34, 287-299, https://doi.org/10.1029/2018PA003503, 2019.

Piela, C., Lyle, M., Marcantonio, F., Baldauf, J., and Olivarez Lyle, A.: Biogenic sedimentation in the equatorial Pacific: Carbon cycling and paleoproduction, 12-24 Ma, Paleoceanography, 27, PA2204, https://doi.org/10.1029/2011PA002236, 2012.

700 Pinet, P.R., Popenoe, P., and Nelligan, D.F.: Gulf Stream: Reconstruction of Cenozoic flow patterns over the Blake Plateau, Geology, 9, 266-270, https://doi.org/10.1130/0091-7613(1981)9<266:GSROCF>2.0.CO;2, 1981.

Ragueneau, O., Tréguer, P., Leynaert, A., Anderson, R.F., Brzezinski, M.A., DeMaster, D.J., Dugdale, R.C., Dymond, J., Fischer, G., François, R., Heinze, C., Maier-Reimer, E., Martin-Jézéquel, V., Nelson, D.M., and Quéquiner, B.: A review of the Si cycle in the modern ocean: recent progress and missing gaps in the application of biogenic opal as a

705 paleoproductivity proxy: Glob. Planet. Change, 26, 317-365, https://doi.org/10.1016/S0921-8181(00)00052-7, 2000. Ravizza, G. and Peucker-Ehrenbrink, B.: The marine ${ }^{187} \mathrm{Os} /{ }^{188} \mathrm{Os}$ record of the Eocene-Oligocene transition: the interplay of weathering and glaciation, Earth Planet. Sci. Lett., 210, 151-165, https://doi.org/10.1016/S0012$821 X(03) 00137-7,2003$.

Ravizza, G., Norris, R. N., Blusztajn, J., and Aubry, M.-P.: An osmium isotope excursion associated with the Late

710 Paleocene thermal maximum: Evidence of intensified chemical weathering, Paleoceanography, 16, 155-163, https://doi.org/10.1029/2000PA000541, 2001.

Renaudie, J., Quantifying the Cenozoic marine diatom deposition history: links to the C and Si cycles, Biogeosciences, 13, 6003-6014, https://doi.org/10.5194/bg-13-6003-2016, 2016.

Richardson, P.L.: Florida Current, Gulf Stream, and Labrador Current, in: Encyclopedia of Ocean Sciences, edited by

715 Steele, J.H., Elsevier, Amsterdam, The Netherlands, 2, 1054-1064, https://doi.org/10.1006/rwos.2001.0357, 2001.

Roughan, M., Keating, S.R., Schaeffer, A., Heredia, C.P., Rocha, C., Griffin, D., Robertson, R., and Suthers, I.M.: A tale of two eddies: The biophysical characteristics of two contrasting cyclonic eddies in the East Australian Current System, J. Geophys. Res. Oceans, 122, 2494-2518, https://doi.org/10.1002/2016JC012241, 2017.

Röhl, U., Norris, R.D., and Ogg, J.G.: Cyclostratigraphy of upper Paleocene and lower Eocene sediments at Blake Nose

720 Site 1051 (western North Atlantic), Geol. Soc. Am. Spec. Pap., 369, 567-589, https://doi.org/10.1130/0-8137-2369-

$8.567,2003$.

Salamy, K.A. and Zachos, J.C.: Latest Eocene-early Oligocene climate change and Southern Ocean fertility: inferences from sediment accumulation and stable isotope data, Palaeogeogr. Palaeoclimatol. Palaeoecol., 145, 61-77, https://doi.org/10.1016/S0031-0182(98)00093-5, 1999.

725 Sanchez-Franks, A. and Zhang, R.: Impact of the Atlantic meridional overturning circulation on the decadal variability of the Gulf Stream path and regional chlorophyll and nutrient concentrations, Geophys. Res. Lett., 42, 9889-9897, https://doi.org/10.1002/2015GL066262, 2015.

Shipboard Scientific Party: Introduction, Proc. ODP, Init. Repts., 171B, 5-10, https://doi.org/10.2973/odp.proc.ir.171B.101.1998, 1998a.

730 Shipboard Scientific Party, Site 1049, Proc. ODP, Init. Repts., 171B, 47-91, https://doi.org/10.2973/odp.proc.ir.171B.103.1998, 1998 b. 
Shipboard Scientific Party, Site 1050, Proc. ODP, Init. Repts., 171B, 93-170, https://doi.org/10.2973/odp.proc.ir.171B.104.1998, 1998c.

Shipboard Scientific Party, Site 1051, Proc. ODP, Init. Repts., 171B, 171-239, https://doi.org/10.2973/odp.proc.ir.171B.105.1998, 1998d.

Shipboard Scientific Party, Site 1052, Proc. ODP, Init. Repts., 171B, 241-319, https://doi.org/10.2973/odp.proc.ir.171B.106.1998, 1998e.

Shipboard Scientific Party, Site 1053, Proc. ODP, Init. Repts., 171B, 321-348, https://doi.org/10.2973/odp.proc.ir.171B.107.1998, 1998f.

740 Sluijs, A., Zeebe, R.E., Bijl, P.K., and Bohaty, S.M.: A middle Eocene carbon cycle conundrum: Nat. Geosci., 6, 429434, https://doi.org/10.1038/ngeo1807, 2013.

Smetacek, V.: Diatoms and the ocean carbon cycle: Protist, 150, 25-32, https://doi.org/10.1016/S1434-4610(99)700064, 1999.

Thomas, D.J., Bralower, T.J., and Jones, C.E.: Neodymium isotopic reconstruction of late Paleocene-early Eocene

745 thermohaline circulation, Earth Planet. Sci. Lett., 209, 309-322, https://doi.org/10.1016/S0012-821X(03)00096-7, 2003. Tréguer, P.J. and De La Rocha, C.L.: The World Ocean silica cycle, Annu. Rev. Mar. Sci., 5, 477-501, https://doi.org/10.1146/annurev-marine-121211-172346, 2013.

Van Cappellen, P., Dixit, S., and van Beusekom, J.: Biogenic silica dissolution in the oceans: Reconciling experimental and field-based dissolution rates, Global Biogeochem. Cycles , 16, 1075, https://doi.org/10.1029/2001GB001431, 2002.

750 van der Ploeg, R., Selby, D., Cramwinckel, M. J., Li, Y., Bohaty, S. M., Middelburg, J. J., and Sluijs, A.: Middle Eocene greenhouse warming facilitated by diminished weathering feedback, Nat. Commun., 9, 2877, https://doi.org/10.1038/s41467-018-05104-9, 2018.

Vahlenkamp, M., Niezgodzki, I., De Vleeschouwer, D., Lohmann, G., Bickert, T., and Pälike, H.: Ocean and climate response to North Atlantic seaway changes at the onset of long-term Eocene cooling, Earth Planet. Sci. Lett., 498, 185-

755 195, https://doi.org/10.1016/j.epsl.2018.06.031, 2018.

Via, R.K. and Thomas, D.J.: Evolution of Atlantic thermohaline circulation: early Oligocene onset of deep-water production in the North Atlantic, Geology, 34, 441-444, https://doi.org/10.1130/G22545.1, 2006.

Wade, B.S. and Kroon, D.: Middle Eocene regional climate instability: Evidence from the western North Atlantic, Geology, 30, 1011-1014, https://doi.org/10.1130/0091-7613(2002)030<1011:MERCIE>2.0.CO;2, 2002.

760 Wade, B.S., Fucek, V.P., Kamikuri, S.-I., Bartol, M., Luciani, V., and Pearson, P.N.: Successive extinctions of muricate planktonic foraminifera (Morozovelloides and Acarinina) as a candidate for marking the base Priabonian, Newsl.

Stratig., 45, 245-262, https://doi.org/10.1127/0078-0421/2012/0023, 2012.

Wade, B.S., O’Neill, J.F., Phujareanchaiwon, C., Ali, I., Lyle, M., and Witkowski, J.: Evolution of deep-sea sediments across the Paleocene-Eocene and Eocene-Oligocene boundaries, Earth-Sci. Rev., 211, 103403,

765 https://doi.org/10.1016/j.earscirev.2020.103403, 2020.

Walker, J. C., Hays, B., and Kasting, J. F.: A negative feedback mechanism for the long-term stabilization of Earth's surface temperature, J. Geophys. Res. Oceans, 86(C10), 9776-9782, https://doi.org/10.1029/JC086iC10p09776, 1981. Westerhold, T., Röhl, U., Donner, B., and Zachos, J. C.: Global extent of early Eocene hyperthermal events: A new Pacific benthic foraminiferal isotope record from Shatsky Rise (ODP Site 1209), Paleoceanography and 
Westerhold, T., Röhl, U., Donner, B., Friederichs, T., Kordesch, W.E.C., Bohaty, S.M., Hodell, D.A., Laskar, J., and Zeebe, R.E.: Late Lutetian Thermal Maximum - crossing a thermal threshold in Earth's climate system?, Geochem. Geophys., 19, 73-82, https://doi.org/10.1002/2017GC007240, 2018 b.

Witkowski, J., Bohaty, S.M., Edgar, K.M., and Harwood, D.M.: Rapid fluctuations in mid-latitude siliceous plankton production during the Middle Eocene Climatic Optimum (ODP Site 1051, western North Atlantic), Mar.

Micropaleontol., 106, 110-129, https://doi.org/10.1016/j.marmicro.2014.01.001, 2014.

Witkowski, J., Harwood, D.M., Wade, B.S., and Bryłka, K.: Rethinking the chronology of early Paleogene sediments in the western North Atlantic using diatom biostratigraphy, Mar. Geol., 424, 106168, https://doi.org/10.1016/j.margeo.2020.106168, 2020a.

780 Witkowski, J., Penman, D., Bryłka, K., Wade, B.S., Matting, S., Harwood, D.M., and Bohaty, S.M.: Early Paleogene biosiliceous sedimentation in the Atlantic Ocean: testing the inorganic origin hypothesis for Paleocene and Eocene chert and porcellanite, Palaeogeogr. Palaeoclimatol. Palaeoecol., 556, 109896, https://doi.org/10.1016/j.palaeo.2020.109896, 2020 b.

Yool, A. and Tyrrell, T.: Role of diatoms in regulating the ocean's silicon cycle, Global Biogeochem. Cycles, 17, 1103, https://doi.org/10.1029/2002GB002018, 2003.

Yool, A. and Tyrrell, T.: Implications for the history of Cenozoic opal deposition from a quantitative model, Palaeogeogr. Palaeoclimatol. Palaeoecol., 218, 239-255, https://doi.org/10.1016/j.palaeo.2004.12.017, 2005.

Zachos, J.C., Quinn, T.M., and Salamy, K.A.: High-resolution ( $10^{4}$ years) deep-sea foraminiferal stable isotope records of the Eocene-Oligocene climate transition, Paleoceanography, 11, 251-266,

790 https://doi.org/10.1029/96PA00571, 1996.

Zachos, J.C., Pagani, M., Sloan, L., Thomas, E., and Billups, K.: Trends, rhythms, and aberrations in global climate 65 Ma to present, Science, 292, 686-693, https://doi.org/10.1126/science.1059412, 2001.

Zachos, J.C., Dickens, G.R., and Zeebe, R.E.: An early Cenozoic perspective on greenhouse warming and carbon-cycle dynamics, Nature, 451, 279-283, https://doi.org/10.1038/nature06588, 2001. 